1 Rare allanite in granulitised eclogites constrains timing of eclogite to granulite transition in Bhutan Himalaya

3 Eleni Wood ${ }^{1}$, Clare J. Warren ${ }^{{ }^{1}}$, Nick M.W. Roberts ${ }^{2}$, Tom W. Argles ${ }^{1}$, Barbara E. Kunz ${ }^{1}$, Ian L.

4 Millar $^{2}$, Sam J. Hammond ${ }^{1}$, Alison Halton ${ }^{3}$

5 1. School of Earth, Environment and Ecosystem Sciences, The Open University, Milton $6 \quad$ Keynes MK7 6AA, UK.

7 2. Geochronology and Tracers Facility, British Geological Survey, Keyworth, Nottingham $8 \quad$ NG12 5GG.

9 3. School of Physical Sciences, The Open University, Milton Keynes MK7 6AA, UK.

* Corresponding author, clare.warren@open.ac.uk

12 Twitter: @geologyclare, @EleniWood, @nickmwroberts, @tomargles, @KunzBE,

15 This manuscript is a non peer-reviewed preprint submitted to Earth ArXiv in November 2021. It 16 has also been submitted to the Journal of Metamorphic Geology for review. 


\section{Rare allanite in granulitised eclogites constrains timing of eclogite to granulite transition in Bhutan Himalaya}

Eleni Wood ${ }^{1}$, Clare J. Warren ${ }^{*}$, Nick M.W. Roberts ${ }^{2}$, Tom W. Argles ${ }^{1}$, Barbara E. Kunz ${ }^{1}$, Ian L. Millar $^{2}$, Sam J. Hammond ${ }^{1}$, Alison Halton ${ }^{3}$

4. School of Earth, Environment and Ecosystem Sciences, The Open University, Milton Keynes MK7 6AA, UK.

5. Geochronology and Tracers Facility, British Geological Survey, Keyworth, Nottingham NG12 5GG.

6. School of Physical Sciences, The Open University, Milton Keynes MK7 6AA, UK.

* Corresponding author, clare.warren@open.ac.uk

\section{Abstract}

During continental collision, crustal rocks are buried, deformed, transformed and exhumed. The rates, timescales and tectonic implications of these processes are determined by linking geochemical, geochronological and microstructural data from metamorphic rock-forming and accessory minerals. Exposures of lower orogenic crust provide important insights into orogenic evolution, but are rare in young continental collision belts such as the Himalaya. In NW Bhutan, eastern Himalaya, a high-grade metamorphic terrane provides a rare glimpse into the evolution and exhumation of the deep eastern Himalayan crust and a detailed case study for deciphering the rates and timescales of deep-crustal processes in orogenic settings. We have collected U-Pb isotope and trace element data from allanite, zircon and garnet from metabasite boudins exposed in the Masang Kang valley in NW Bhutan. Our observations and data suggest that allanite cores record growth under eclogite facies conditions ( $\left.>17 \mathrm{kbar} \sim 650^{\circ} \mathrm{C}\right)$ at $\mathrm{ca} .19 \mathrm{Ma}$, zircon inner rims and garnet cores record growth during decompression under eclogite facies conditions at ca 17-15.5. Ma, and symplectitic allanite rims, garnet rims and zircon outer rims record growth under granulite facies conditions at $\sim 9-6 \mathrm{kbar} ;>750^{\circ} \mathrm{C}$ at ca. $15-14.5 \mathrm{Ma}$. Allanite 
44 is generally considered unstable under granulite-facies conditions and we think that this is the first recorded example of such preservation, likely facilitated by rapid exhumation. Our new observations and petrochronological data show that the transition from eclogite to granulite

47 facies conditions occurred within 4-5 Ma in the Eastern Himalaya. Our data indicate that the exhumation of lower crustal rocks across the Himalaya was diachronous and may have been facilitated by different tectonic mechanisms.

Key Words: Geochronology, allanite, zircon, garnet, eclogite, granulite, Bhutan, Himalaya

\section{Introduction}

Deciphering the evolution of continental collisional belts through time relies on constraining metamorphic rock histories to determine the temperature and pressure conditions at different times in different places in the orogen. Determining accurate and precise pressuretemperature-time paths in turn requires linking absolute and relative geological ages to specific metamorphic conditions. A comparison between these paths and those from neighbouring tectonic units sheds light on the tectonic history of the orogen as a whole.

The Himalayan orogen, formed over the last 50 Ma during the collision between the Indian and Asian continents, is the largest active continental collision zone on Earth. Its geological youth allows the rates and timescales of its tectonic evolution to be determined with high geochronological precision. These rates and timescales can then be used to inform the geological history of older orogens where the analytical uncertainty in the geochronological data hide important detail.

High-pressure (>1.5 GPa) metamorphic rocks, and specifically eclogites, provide information about deep crustal and shallow mantle processes during orogenesis. In the Himalaya, two distinctive varieties of eclogite have been described from the northwestern and central parts of the orogen. High to ultra-high pressure (HP-UHP; $\geq 2.7 \mathrm{GPa}$ ) ca. 50-47 Ma (Eocene) eclogites have been reported exposed close to, and in the footwall of, the suture zone between the Indian and Asian plates in Tso Morari, India and Kaghan, Pakistan (Chaudhry \& Ghazanfar, 1987; 
71 O'Brien, 2019; Pognante \& Spencer, 1991; Sigoyer et al., 1997). These rocks record the

72 subduction of the leading continental margin of India as it subducted beneath the Asian

73 continent during the early stages of collision (Pognante et al., 1993; Sigoyer et al., 1997). In the central and eastern Himalaya (Ama Drime, Sikkim and Bhutan), younger, ca. 26-15 Ma (Oligocene to Miocene) eclogites have been reported from the highest structural levels of the high-metamorphic grade Greater Himalayan Sequence (GHS), close to, and in the footwall of, the normal-sense detachment that separates the GHS from non-metamorphosed Tethyan oceanic sediments (Corrie et al., 2010; Cottle et al., 2009; Groppo et al., 2007; Grujic et al., 2011a; Kali et al., 2010; Kellett et al., 2014; Liu et al., 2007; Lombardo \& Rolfo, 2000; Regis et al., 2014a; Rolfo et al., 2008; Y. Wang et al., 2017; Warren et al., 2011). This structure is exposed several hundred kilometers south of the India-Asia suture, so these eclogites, mostly overprinted by a granulite-faces assemblage have been interpreted as representing metamorphism in the deep orogenic crust during the later stages of collision.

The differences in tectonic evolution of these high-pressure rocks is important for understanding orogenic evolution in general and the evolution of the Himalaya in detail. The central and eastern Himalayan granulitised eclogites not only provide important information about the evolution of the lower orogenic crust, but also important constraints on the tectonic mechanisms that exhumed these rocks so relatively early in Himalayan orogenic evolution. The details of their metamorphic pressure-temperature-time paths and the mechanism(s) by which they were exhumed to the surface remain cryptic and debated e.g. (Grujic et al., 2011a; Kellett et al., 2009; J.-M. Wang et al., 2021). Apart from in Ama Drime, where new evidence suggests that the eclogite to granulite transition might have taken place slowly, over 10 Ma (J.-M. Wang et al., 2021), much of the data suggest that the timing of the transition from eclogite to granulite facies was geologically very rapid and that the record of this transition is cryptically recorded. This in turn raises further questions about the heat source required to boost the temperature by ca $100-150^{\circ} \mathrm{C}$ over $1-2 \mathrm{Ma}$ and the tectonic mechanism(s) that drove the exhumation of these enigmatic rocks. 
Thus far, most geochemical and geochronological studies of these rocks have focussed on "traditional" geochronometers such as zircon, garnet and rutile. We have discovered allanite in two samples from NW Bhutan, one of which we analysed in detail. Allanite ([Ca, REE,Th $]_{2}[\mathrm{Al}, \mathrm{Fe}$ $\left.{ }^{3+}\right]_{3}\left(\left[\mathrm{SiO}_{4}\right]_{3} \mathrm{OH}\right)$ is a REE-bearing epidote group mineral that can be dated using the U-Th- $\mathrm{Pb}$ isotope system (Darling et al., 2012; El Korh, 2014; Engi, 2017; Gregory et al., 2007; Loury et al., 2016; Smye et al., 2014). It is also petrochronologically useful, in that it plays a major role in the exchange of REE and actinides between different minerals in eclogite-facies rocks during their metamorphic evolution (Smye et al., 2014). Although allanite is known to be stable across a broad range of bulk compositions and PT conditions, its occurrence in mafic rocks it is most commonly restricted to greenschist through to eclogite-facies assemblages (Franz et al., 1986; Gieré \& Sorensen, 2004). Allanite is generally considered unstable under granulite-facies conditions and we think that our samples document the first example of such preservation.

Here we constrain the pressure-temperature-time path of one such eclogite occurrence in the Masang Kang valley of NW Bhutan. We present new U-Pb and Lu-Hf geochronology combined with trace element data from allanite, zircon and garnet. The data suggest that allanite cores record growth under eclogite facies conditions, whereas the symplectitic allanite rims record growth during decompression at high temperatures across the eclogite to granulite facies transition. These spatially-constrained data add to an increasingly detailed dataset that suggests decompression and heating of this cryptic tectono-metamorphic unit in NW Bhutan over a short period of only 2-3 Ma and indicate that exhumation of deep crustal rocks is both diachronous and potentially driven by different mechanisms across the Himalaya. The preservation of allanite, rarely documented in granulite-facies rocks, was likely facilitated by rapid cooling following decompression.

\section{Central and Eastern Himalayan eclogites}

The attainment of eclogite-facies conditions in these central and eastern areas of the Himalaya has typically been inferred from a combination of microtextures and trace element signatures in metabasites, including symplectitic intergrowths of low-jadeite clinopyroxene and oligoclase 
interpreted as breakdown products of omphacite (Groppo et al., 2007; Grujic et al., 2011a; Lombardo \& Rolfo, 2000) and the absence of a negative Eu anomaly in chemically-distinct zones of both garnet and zircon (Grujic et al., 2011a; J.-M. Wang et al., 2021; Warren et al., 2011). The latter suggests a plagioclase-free environment during garnet and zircon growth, corroborated by the observation that feldspar presence is texturally restricted to post-peak decompression textures such as garnet --> orthopyroxene + plagioclase feldspar, omphacite --> clinopyroxene + plagioclase feldspar (Chakungal et al., 2010; Groppo et al., 2007; Grujic et al., 2011a). Little-to-no direct major elemental evidence for eclogite facies metamorphism appears to be preserved (e.g. through garnet and clinopyroxene compositions), though rare omphacite inclusions have been described included in garnet and zircon in Ama Drime (J.-M. Wang et al., 2021); further omphacite compositions have been recovered by integration of clinopyroxene + plagioclase symplectitic breakdown products from electron microprobe analyses (J.-M. Wang et al., 2021).

Eclogite facies conditions estimated for the eclogites exposed in Ama Drime range from >15 kbar at $>580^{\circ} \mathrm{C}$ (Groppo et al., 2007) to $20 \mathrm{kbar}$ at $710 \pm 50^{\circ} \mathrm{C}$ in rocks that preserve omphacite inclusions or where compositions of plagioclase-clinopyroxene symplectites have been reintegrated to estimate the earlier compositions (Corrie et al., 2010; J.-M. Wang et al., 2021; Y. Wang et al., 2017). Similar peak pressures and peak temperatures of $\sim 760^{\circ} \mathrm{C}$, were estimated for NW Bhutan samples on the basis of similar textures and mineral compositions and the results of Ti-in-zircon thermometry (Grujic et al., 2011a; Warren et al., 2011).

A pervasive granulite-facies overprint is recorded in all the central and eastern Himalayan high pressure metabasites by an assemblage of $\mathrm{Grt}+\mathrm{Cpx}+\mathrm{PI}+\mathrm{Opx}+\mathrm{Amph}+\mathrm{Bt}+\mathrm{Ilm}+\mathrm{FeOx}+\mathrm{Qz}+$ melt. Reaction textures associated with decompression at high temperatures include: 1) Symplectites of clinopyroxene and plagioclase after omphacite; 2) Symplectites of fine-grained orthopyroxene and anorthite and moats of plagioclase surrounding garnet; 3) Replacement of rutile by ilmenite (and titanite); 4) Replacement of phengite by biotite (Groppo et al., 2007; Grujic et al., 2011a; Lombardo \& Rolfo, 2000; Y. Wang et al., 2017). 
153 In Ama Drime, evidence is preserved for mineral assemblage evolution during granulite-facies metamorphism, with the formation of $\mathrm{Cpx}+\mathrm{PI}$ after Omp and the formation of Opx $+\mathrm{PI}$ after Grt. Pseudosection modelling suggested that these reactions were constrained at 0.8 to $1.0 \mathrm{GPa}$ kbar at $>750^{\circ} \mathrm{C}$ and $0.4 \mathrm{GPa}$ and ca. $750^{\circ} \mathrm{C}$ respectively (Groppo et al., 2007). Peak temperatures of up to $900-930^{\circ} \mathrm{C}$ (implying UHT conditions) have also been suggested for Ama Drime samples on the basis of mineral relicts, mineral textures and thermobarometric calculations (J.-M. Wang et al., 2021). Lower peak metamorphic conditions have been proposed for the granulite-facies overprint on eclogite-facies assemblages in north Sikkim (>4 kbar, $>750^{\circ} \mathrm{C}$; (Rolfo et al., 2008), the Jomolhari Massif in W Bhutan (7-10 kbar, $750^{\circ} \mathrm{C}$; (Regis et al., 2014b)), and in NW Bhutan (8-10 kbar, 750-800 C; (Warren et al., 2011)).

The timing of the formation of the eclogite-facies assemblage(s) and their replacement by granulite facies assemblages during decompression are still somewhat unclear. Zircon rims with weak negative Eu anomalies have been interpreted as recording the timing of their growth in a feldspar-free environment between $15.3 \pm 0.3-14.4 \pm 0.3 \mathrm{Ma}$ in NW Bhutan (Grujic et al., 2011a) and 14.9 \pm 0.7-13.9 $\pm 1.2 \mathrm{Ma}$ in the Dinggye region of the Ama Drime Massif (Y. Wang et al., 2017). Older evidence for eclogite-facies metamorphism in the Ama Drime Massif has been suggested by U-Pb dating of monazite and zircon cores at 30-29 Ma (J.-M. Wang et al., 2021) and Lu-Hf dating of garnet at 20.7 $\pm 0.4 \mathrm{Ma}$ (Corrie et al., 2010) and 37 - $34 \mathrm{Ma}$ (Kellett et al., 2014).

172 The timing of granulite-facies overprint is interpreted to be recorded by the growth of monazite 173 in the metasedimentary host gneisses, which, in NW Bhutan, yield LA-ICP-MS U-Pb ages 174 between $15.4 \pm 0.8-13.4 \pm 0.5 \mathrm{Ma}$, i.e. overlapping with the zircon ages (Warren et al., 2011). 175 Thin zircon rims in Ama Drime metabasites have yielded dates of $17.6 \pm 0.3 \mathrm{Ma}$ (Li et al., 2003) and between 14 and $13 \pm 1$ Ma (Kellett et al., 2014; Lombardo et al., 2016) both of which have

177 been interpreted as recording the timing of the granulite facies overprint. Monazite and xenotime in the host metapelites yield a similarly wide range of dates interpreted as recording 179 the timing of granulite metamorphism, between 21-19 Ma (Y. Wang et al., 2017) and 14-12 Ma 180 (Cottle et al., 2009). Other researchers, however, have attributed similar dates to the final 
181 crystallisation of decompression-related melts at temperatures $<650^{\circ} \mathrm{C}$ (Groppo et al., 2007;

182 Kali et al., 2010; J.-M. Wang et al., 2021; Y. Wang et al., 2017).

183 The high-grade metabasites in NW Bhutan are exposed in meter-scale boudins hosted by felsic

184 gneiss in the valleys surrounding Bhutan's highest mountain, the Masang Kang (Figure 1), 2-3

$185 \mathrm{~km}$ beneath the South Tibetan Detachment System (Chakungal et al., 2010). An eclogite-facies

186 assemblage of garnet, omphacitic pyroxene and quartz is heavily overprinted by a granulite-

187 facies assemblage of augitic clinopyroxene, orthopyroxene, plagioclase and hornblende. The

188 boudins are hosted in migmatitic sillimanite-grade metasediments and orthogneiss.

191 The high-grade mafic rocks in NW Bhutan are exposed in meter-scale boudins hosted by felsic 192 gneiss in the valleys surrounding Bhutan's highest mountain, the Masang Kang (Figure 1), 2-3 $193 \mathrm{~km}$ beneath the South Tibetan Detachment System (Chakungal et al., 2010). An eclogite-facies 194 assemblage of garnet, omphacitic pyroxene and quartz is heavily overprinted by a granulite195 facies assemblage of augitic clinopyroxene, orthopyroxene, plagioclase and hornblende. The 196 boudins are hosted in migmatitic sillimanite-grade metasediments and orthogneiss. 


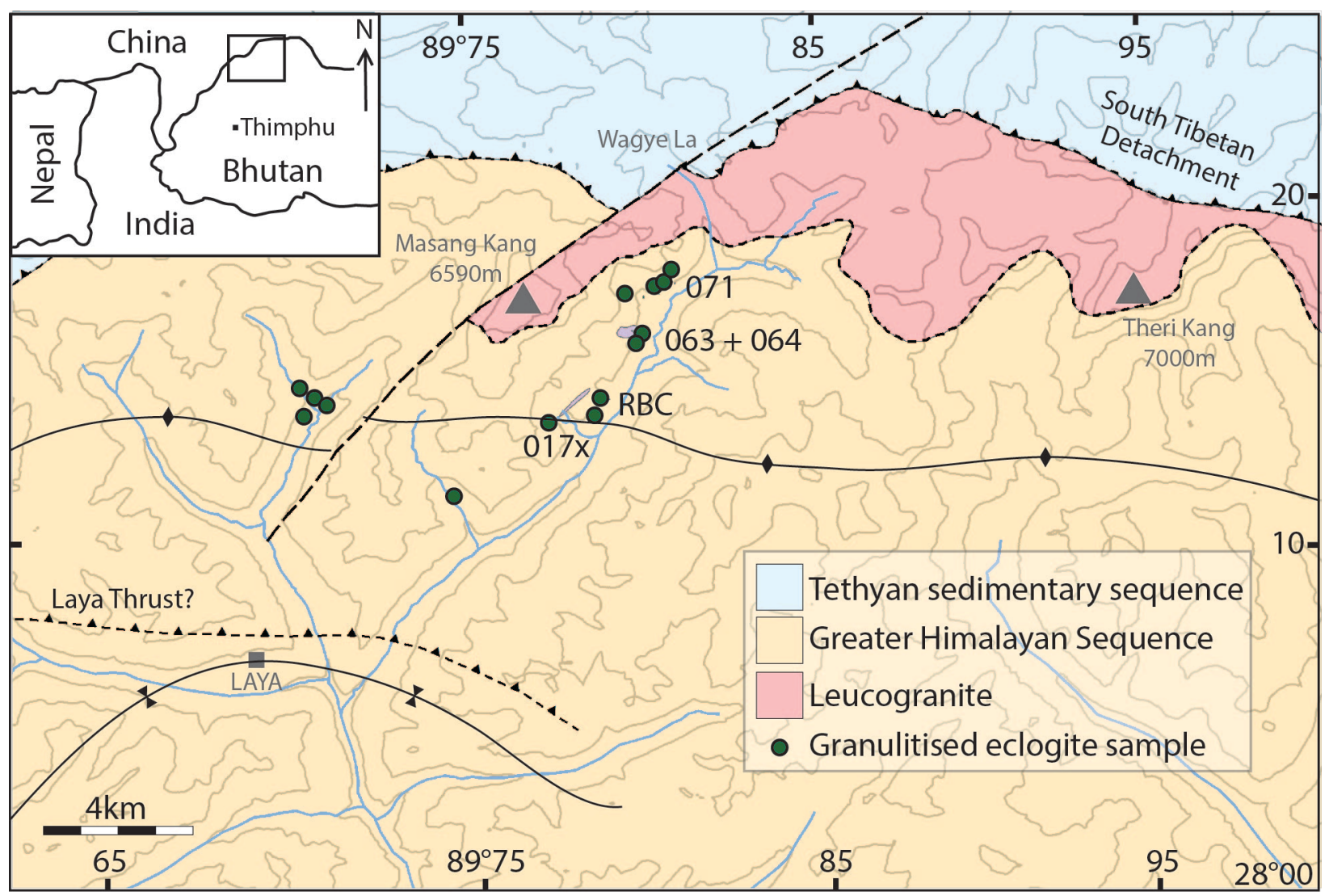

Figure 1: Geological sketch map of NW Bhutan showing the sampling localities for the reported samples, contour lines at 500m intervals (pale grey), rivers (blue) and simplified structural information (black). The inset shows the location of the study area in the Eastern Himalaya. Lat/long information in degrees and decimal minutes.

\section{Sample petrology}

Five mafic granulitised eclogite samples (EWB 071, 063, 064, 017x, and RBC; locations on Figure 1) were selected for study. All samples contain garnet, clinopyroxene, quartz, plagioclase, hornblende, zircon, apatite, ilmenite and iron oxide. EWB 071 and 017x also contain orthopyroxene and biotite; EWB 071 and 064 also contain rare allanite, rutile and titanite. Extensive chemical datasets of U-Pb (zircon) and Lu-Hf (garnet) isotopes, and major and trace element concentrations were collected from EWB 071; these are complemented and 
supplemented by less extensive datasets collected from the other samples. Whole-section photographic scans are documented in Supplementary Figure 1.

\section{EWB071}

Sample EWB 71 (Figure 2) is the sample with the most intermediate composition of the studied collection. It is strongly domainal on a $\mathrm{cm}$ scale, with variations in the modal proportions of mafic (Grt, Cpx, $\mathrm{Hbl})$ and felsic $(\mathrm{Qz}, \mathrm{Pl})$ minerals and variations in the retrogressive overprint of the more mafic domains (mineral abbreviations follow (Whitney \& Evans, 2010) throughout). The domain boundaries between more mafic and more felsic domains are diffuse.

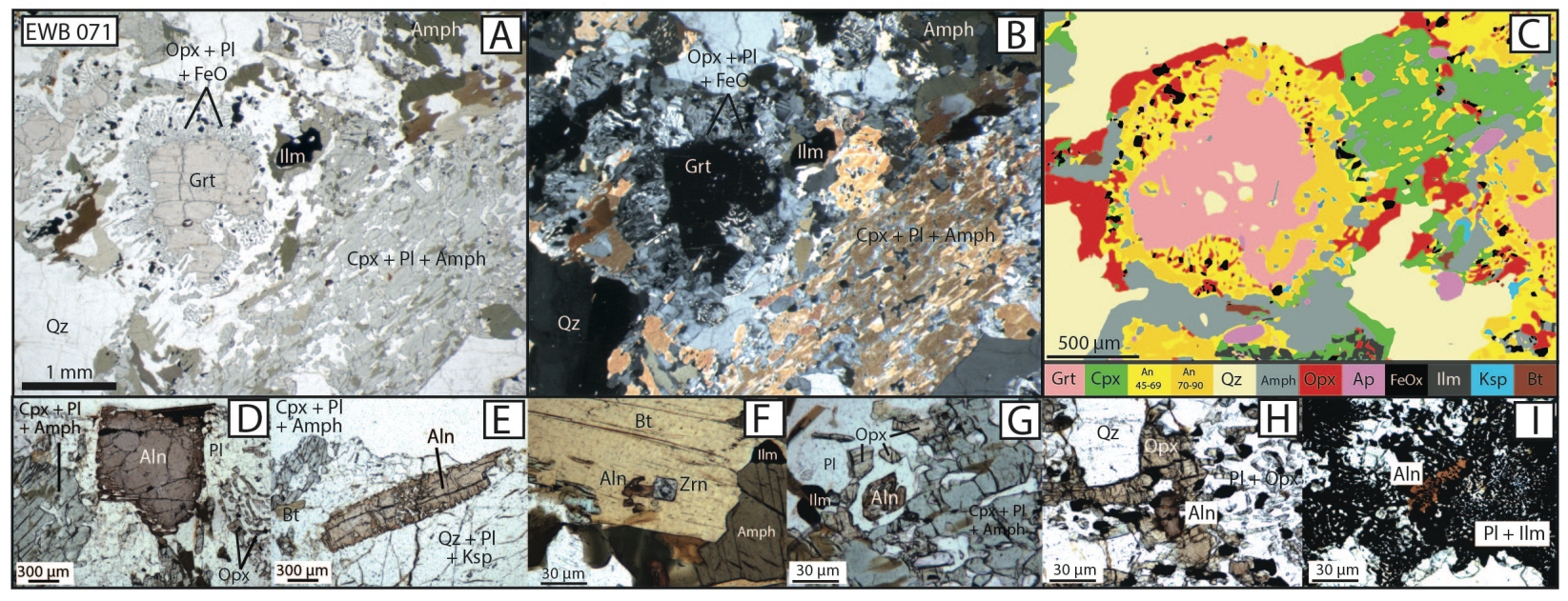

Figure 2: Images of sample EWB 071. A. Overview photomicrograph showing mineralogy and textures. Garnets are highly corroded and are replaced proximally by symplectites of orthopyroxene + plagioclase, and distally by amphibole + plagioclase. Omphacite has been completely replaced by a symplectite of clinopyroxene + plagioclase + amphibole. B. Same field of view as $(A)$ but under crossed-polars. C. False colour mineral map produced by XMapTools (Lanari et al., 2014) showing the mineral distribution in a different area of the thin section. D-I. Photomicrographs showing different allanite morphologies and sizes in a range of textural positions. D-E. 500 um tabular lath-like grains with dark vermicular rims intergrown with plagioclase feldspar. F. Corroded inclusions in biotite in textural association with zircon, G-H. Prismatic symplectised grains intergrown with plagioclase in association with granulite facies 
orthopyroxene, clinopyroxene and plagioclase. I. Grain growing in close association with symplectic growth of ilmenite + plagioclase.

The more mafic domains originally contained garnet ( $30-40 \%$ by volume), clinopyroxene (likely omphacitic; $30-40 \%$ by volume) and quartz. Both the garnet and clinopyroxene are now highly corroded. Garnet remnants are rimmed by fine-grained symplectites of orthopyroxene + plagioclase \pm iron oxide. These fine symplectites are themselves replaced by coarser symplectites of amphibole + plagioclase more distally from the garnet and/or in more retrogressed portions of the sample. Inclusions in garnet are primarily quartz, with minor biotite, zircon, iron oxides, apatite, ilmenite and rutile. Granular orthopyroxene separates former garnet (or the replacement $\mathrm{Opx}+\mathrm{PI}$ or $\mathrm{Hbl}+\mathrm{PI}$ symplectites) from quartz (Figure $2 \mathrm{C}$ ).

The original, likely omphacitic, pyroxene (c.f. (Groppo et al., 2007) has universally been replaced by symplectitic intergrowths of augitic clinopyroxene and sodic plagioclase with minor interstitial hornblende (green mineral in Figure 2C). More retrogressed regions contain higher proportions and larger grains of hornblende. The clinopyroxene grains are in general optically continuous.

Allanite occurs in a range of textural contexts in EWB 071, including within the matrix plagioclase + pyroxene assemblage, at margins of quartz-feldspar assemblages, and intergrown with ilmenite + pyroxene. Tabular or prismatic grains between $0.1-1 \mathrm{~mm}$ in length are present in both mafic and felsic domains. Larger grains contain pale pink, faintly pleochroic cores and darker brown 10-50 $\mu \mathrm{m}$-wide rims (Figure 2D-E); rutile inclusions are common. The rims are symplectitically intergrown with plagioclase feldspar. Smaller grains $(<0.5 \mathrm{~mm})$ have similar colouring and characteristics to the dark rims of large grains and are commonly wholly symplectised with anorthitic plagioclase or with ilmenite \pm clinopyroxene \pm iron oxide (Figure $2 \mathrm{~F}-\mathrm{I})$.

The more felsic domains consist of coarse quartz, K-feldspar and plagioclase. K-feldspar grains displaying lamellar twinning are penetrated by fine vermicular myrmekites and perthites. Corroded biotite flakes are locally present, associated with the myrmekite textures. 
Sample EWB 017x is a coarse-grained, relatively undeformed metabasite (Figure 3A). Garnet forms roughly equant idiomorphic grains that vary from relatively intact to being nearly completely replaced. Garnet cores contain a higher density of inclusions (quartz, amphibole,

263 ilmenite, clinopyroxene, zircon, plagioclase) than the rims (apatite and zircon). In many cases

264 the cores have been preferentially replaced compared to the rims, leaving atoll structures.

265 Garnet is replaced by symplectites of zoned plagioclase feldspar, vermicular orthopyroxene and 266 granular iron oxide, themselves being later replaced by interfingering intergrowths of

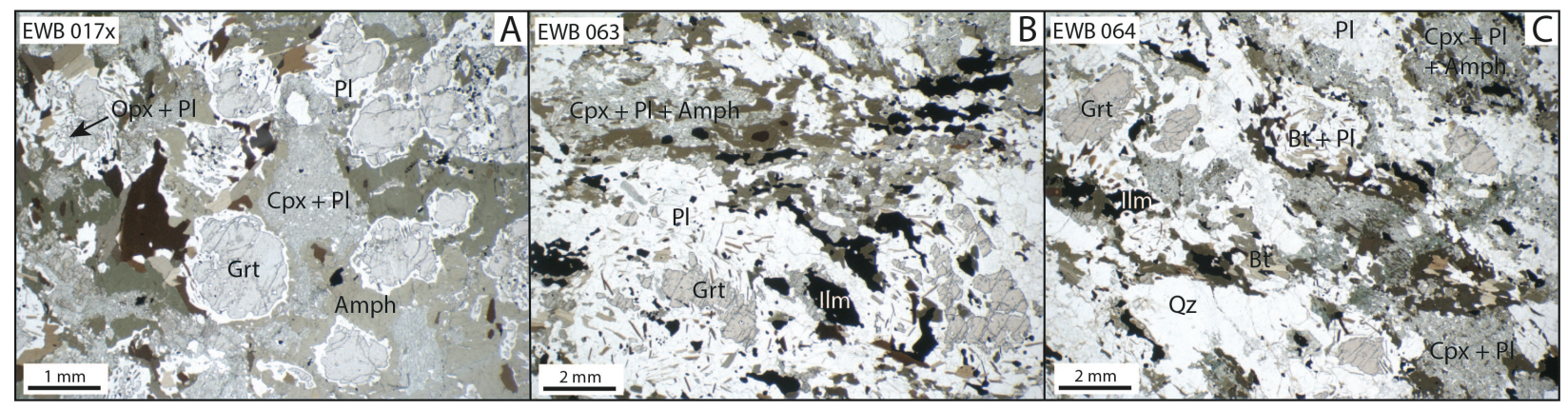

Figure 3: Photomicrographs of samples EWB017x, 063 and 063 in plane polarised light.

271 Original (likely omphacitic) clinopyroxene is now universally replaced by a lacy symplectite of

272 clinopyroxene + plagioclase, in places mantled by granular orthopyroxene. Millimetre-scale

273 biotite laths are intergrown with garnet and pyroxene; a number of grains have undergone

274 replacement by hornblende and plagioclase at their rims. Quartz is a minor component and 275 found predominantly as inclusions in garnet. 
EWB063, 064, RBC

Samples EWB 063, 064 and RBC are mineralogically similar, medium-grained, lightly foliated metabasites (Figures 3B,C). In the more mafic (garnet + clinopyroxene) domains, remnant garnet cores containing quartz inclusions are surrounded by granular plagioclase + biotite or plagioclase + amphibole coronas; in some places no garnet remains. Original (likely omphacitic) clinopyroxene is now replaced by a symplectite of augitic clinopyroxene and plagioclase, some of which has later been replaced by hornblende. Patches of coarse myrmekite are present along grain boundaries in the mafic domains.

The more felsic domains, which have diffuse boundaries to the more mafic domains, contain quartz, plagioclase and K-feldspar. K-feldspar grains with lamellar twinning are penetrated by radiating fine vermicular myrmekites and perthites. Patches of myrmekite share lobate grain boundaries with larger K-feldspar grains.

In sample EWB 064 a more mafic garnet and clinopyroxene-bearing layer is separated from a more intermediate layer by a felsic vein with diffuse boundaries. Rare allanite, typically 10 s of $\mu \mathrm{m}$ in length, dark brown and faintly pleochroic, is associated with this vein. Allanite rims are embayed and intergrown with plagioclase (similar to those in EWB 071, Figure 2G-H).

\section{Methods}

Polished sections of all samples were prepared and analysed at The Open University (OU), UK. Zircon-bearing samples were crushed and separated using heavy mineral separation at the Geochronology and Tracers Facility (GTF), British Geological Survey, Keyworth, UK. Samples selected for Lu-Hf garnet analysis were crushed at the OU, and further processed at the GTF. Cathodoluminescence images of zircon were taken using a dual beam FEI Quanta 3D Scanning Electron Microscope with a Deben Centaurus Cathodoluminescence detector at the OU. A detailed description of the sample preparation and analytical protocols is provided in Supplementary Materials 1. 
Major element analysis and element maps of mineral phases were performed at the OU using a Cameca SX100 microprobe with 5 wavelength dispersive spectrometers. All maps were processed using the software package XMapTools (Lanari et al., 2014).

Concentrations and isotopic ratios of $\mathrm{U}-(\mathrm{Th})-\mathrm{Pb}$ isotopes in zircon (grain mounts) and allanite (in-situ) were measured at the GTF using a Nu Instruments AttoM HR sector-field singlecollector inductively coupled plasma mass spectrometer (SC-ICP-MS) coupled with a New Wave Research 193UC laser ablation system fitted with a New Wave Research TV2 cell. Methods are previously described in (Spencer et al., 2014) and (Smye et al., 2014) for zircon and allanite, respectively. Individual zircon dates $\left({ }^{206} \mathrm{~Pb} /{ }^{238} \mathrm{U}\right)$ are common lead corrected using a ${ }^{207} \mathrm{~Pb}$-based correction with a terrestrial lead composition at 20 Ma (Stacey \& Kramers, 1975), and assuming concordance. Allanite dates are based on lower intercept values on Tera-Wasserburg plots.

Lu-Hf isotopes of whole rock and dissolved garnet separates were measured at the GTF using a Thermo-Scientific Neptune Plus multi-collector ICP-MS mass spectrometer.

Trace element concentrations in garnet, zircon and allanite were analysed the OU by LA-ICPMS using a Photon Machines Analyte G2 193 nm excimer laser system equipped with a HelEx II 2-volume cell coupled to an Agilent 8800 ICP-MS.

Bulk rock compositions (for thermodynamic modelling) were obtained by XRF analysis at the University of Leicester. Major and trace element compositions of the fusion beads and pressed powder pellets were measured on a PANalytical Axios Advanced X-ray fluorescence spectrometer following methods described by (Knott et al., 2016).

Zircon crystallisation temperatures were calculated using the Ti-in-zircon thermometer (Ferry \& Watson, 2007) assuming silica and titanium activities of 1 (both quartz and a Ti-bearing phase such as rutile or ilmenite were present in all samples). Average pressures and temperatures were calculated for metabasite samples EWB 017x, 064 \& 071 using the avPT method in THERMOCALC (Powell \& Holland, 1988). A pseudosection to interrogate the metamorphic evolution of EWB 071 was modelled using Theriak-Domino (de Capitani \& Petrakakis, 2010). The 10-component NCKFMASHTO ( $\left.\mathrm{Na}_{2} \mathrm{O}-\mathrm{CaO}-\mathrm{K}_{2} \mathrm{O}-\mathrm{FeO}-\mathrm{MgO}-\mathrm{Al}_{2} \mathrm{O}_{3}-\mathrm{SiO}_{2}-\mathrm{H}_{2} \mathrm{O}-\mathrm{TiO}_{2}-\mathrm{O}_{2}\right)$ composition system was used to model a bulk composition of $\mathrm{SiO}_{2} 57.46 \% \mathrm{Al}_{2} \mathrm{O}_{3} 16.79 \%, \mathrm{CaO}$ 
$3339.08 \%, \mathrm{MgO} 6.33 \%, \mathrm{FeO} 13.08 \%, \mathrm{~K}_{2} \mathrm{O} 1.43 \%, \mathrm{Na}_{2} \mathrm{O} 2.63 \%, \mathrm{TiO}_{2} 1.89 \%$ suggested by the XRF

334 results; $\mathrm{H}_{2} \mathrm{O}$ was modelled as $3.9 \%$.

335

336 Results

337 The major element data collected from all major phases are reported in Supplementary Table 1.

338 The trace element concentrations determined by LA-ICP-MS are reported in Supplementary

339 Table 2. The full geochronology datasets are reported in Supplementary Table 3. All

340 geochronology data are plotted using IsoplotR (Vermeesch, 2018).

341

342 Allanite

343 Chemical maps generated by electron microprobe and LA-ICP-MS spot data show that allanite

344 in EWB 071 records two distinct chemical domains. Large (>100 $\mu \mathrm{m})$ grains (e.g. G2 in Figure 4)

345 preserve a patchy, relatively Ca-, Al-enriched, core (domain 1) and a relatively REE, Th, Fe, Mg

346 and $\mathrm{Ti}$-enriched rim (domain 2) (Table 2). Smaller symplectised grains and grains preserved in

347 ilmenite + clinopyroxene symplectites (e.g. G7 in Figure 4) consist entirely of domain 2. 


\section{EWB 071 Aln 2}

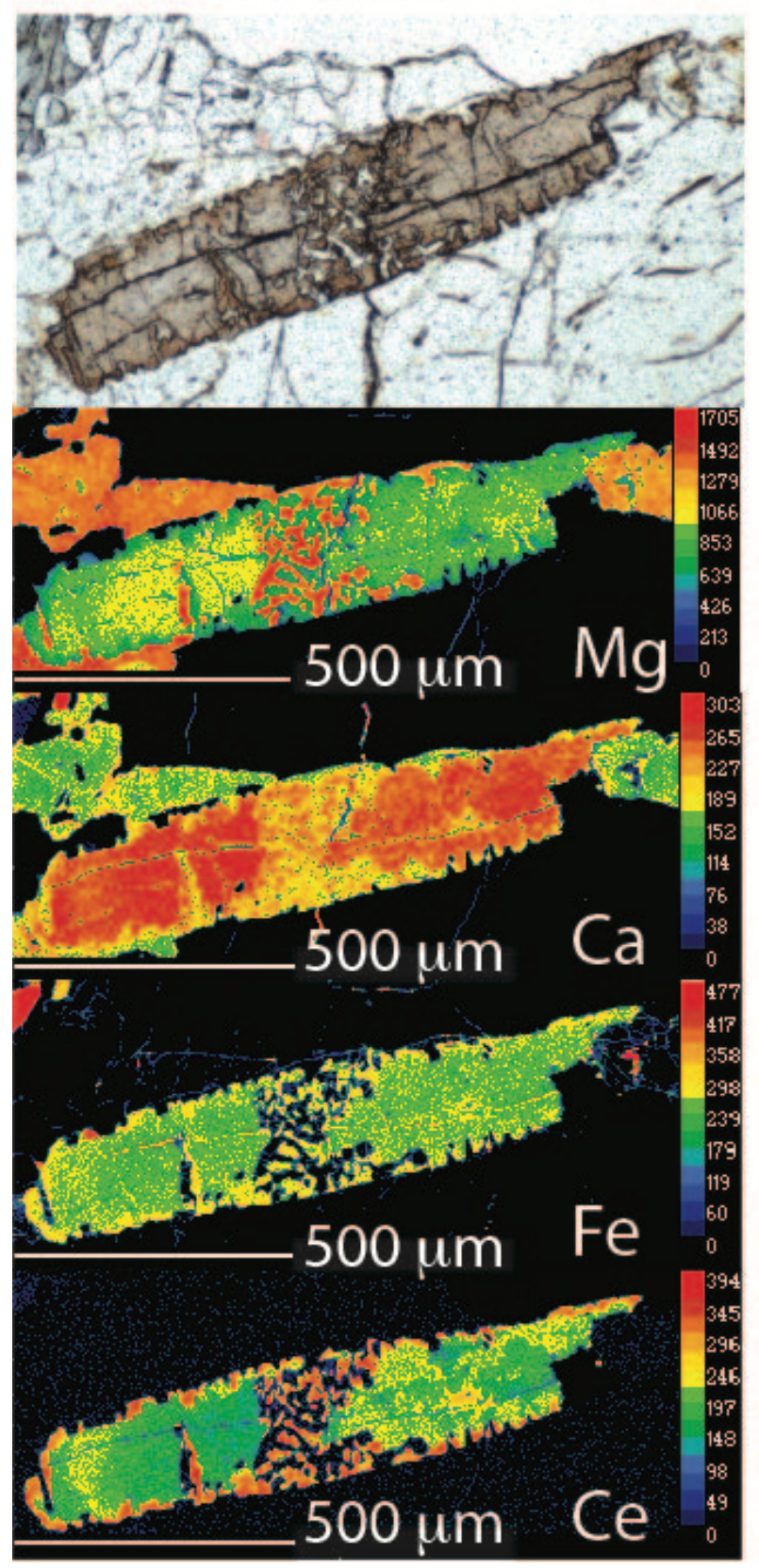

\section{EWB 071 Aln 7}

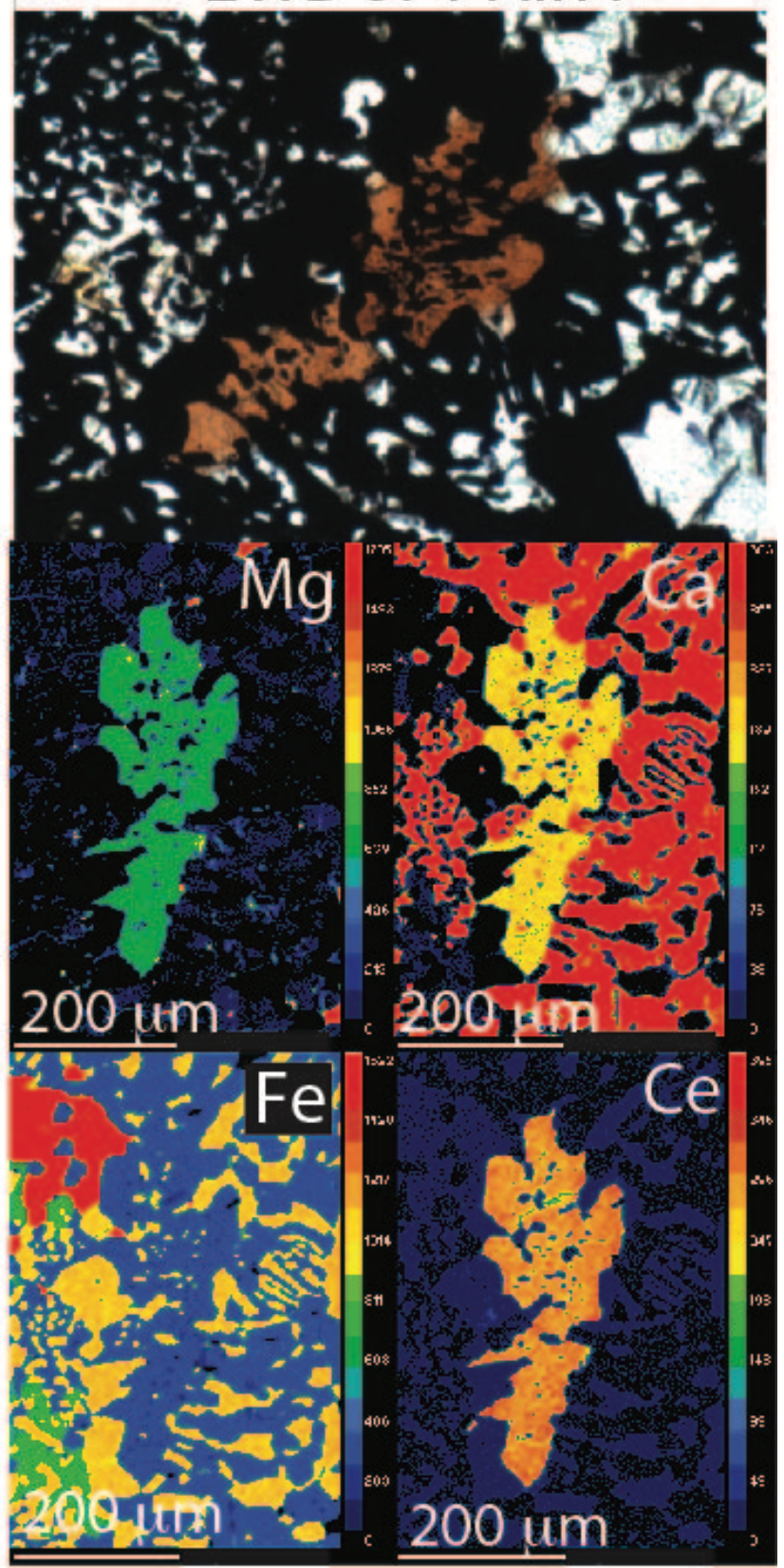

349 Figure 4. False colour X-ray element maps of typical allanite grains in EWB071. The intensities

350 are scaled identically across the grains (blues = low concentration, reds $=$ high). Note the Ca, Fe

351 and Ce concentrations in grain G7 are similar to the concentrations in the rim of grain G2. 
354 Table 2: Allanite major element data.

\begin{tabular}{|c|c|c|}
\hline & Av core & Av rim \\
\hline & Wt \% & Wt \% \\
\hline Number of analyses & 43 & 29 \\
\hline $\mathrm{SiO}_{2}$ & 33.21 & 31.51 \\
\hline $\mathrm{MgO}$ & 0.69 & 0.95 \\
\hline $\mathrm{CaO}$ & 15.46 & 12.03 \\
\hline $\mathrm{MnO}$ & 0.09 & 0.12 \\
\hline $\mathrm{FeO}$ & 11.11 & 12.57 \\
\hline $\mathrm{Al}_{2} \mathrm{O}_{3}$ & 19.92 & 16.54 \\
\hline $\mathrm{Y}_{2} \mathrm{O}_{3}$ & 0.02 & 0.04 \\
\hline $\mathrm{La}_{2} \mathrm{O}_{3}$ & 2.98 & 4.76 \\
\hline $\mathrm{Ce}_{2} \mathrm{O}_{3}$ & 6.91 & 10.26 \\
\hline $\mathrm{Pr}_{2} \mathrm{O}_{3}$ & 1.09 & 1.50 \\
\hline $\mathrm{Nd}_{2} \mathrm{O}_{3}$ & 2.59 & 3.38 \\
\hline $\mathrm{Sm}_{2} \mathrm{O}_{3}$ & 0.31 & 0.34 \\
\hline $\mathrm{Gd}_{2} \mathrm{O}_{3}$ & 0.00 & 0.00 \\
\hline $\mathrm{TiO}_{2}$ & 0.37 & 0.69 \\
\hline $\mathrm{ThO}_{2}$ & 0.92 & 2.05 \\
\hline $\mathrm{UO}_{2}$ & 0.10 & 0.10 \\
\hline $\mathrm{Total}$ & 95.78 & 96.83 \\
\hline
\end{tabular}

356 Domain 1 records lower LREE and HREE concentrations and a smaller EuN/Eu* ${ }_{N}(0.64-0.98$;

357 average 0.85; Figure 5A) compared to domain 2 (0.28-0.56; average 0.44).

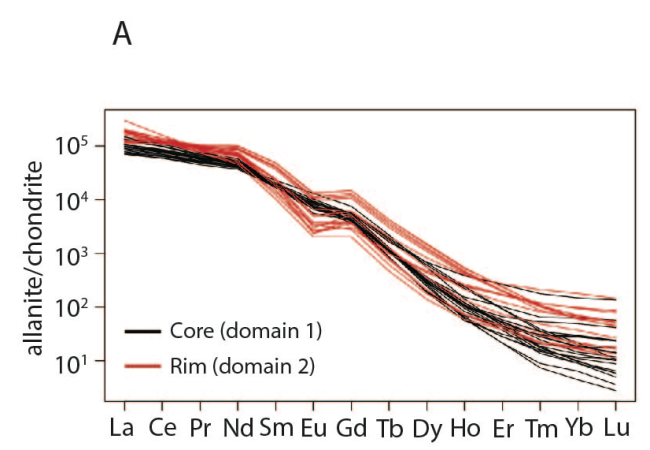

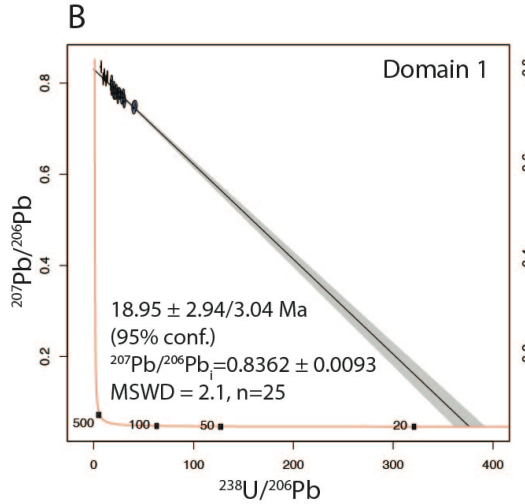

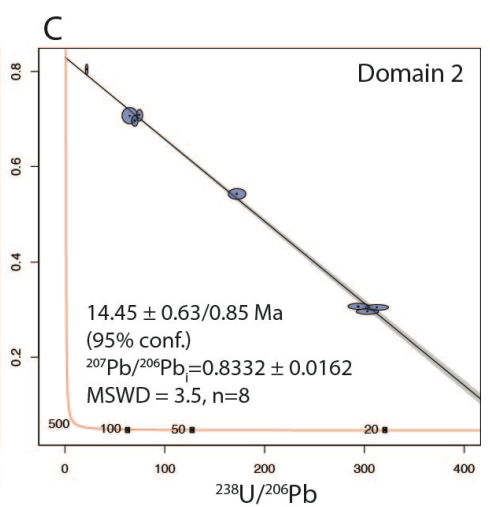

Figure 5 A. Chondrite-normalised rare earth element plot for the allanite cores (domain 1) and rims (domain 2). B and $\mathrm{C}$. U-Pb Tera-Wasserburg plots showing the dates obtained for allanite 
361 core and rim domains. The first quoted uncertainty is analytic, the second is systematic. The 362 three analyses with the lowest common-Pb concentrations in C were measured on grain $\mathrm{G} 7$

363 (Figure 4) that forms an intergrowth with ilmenite and clinopyroxene, likely after titanite.

Thirty-two U-(Th)-Pb spots placed by textural location based on mapped Ce concentrations

366 across seven allanite grains in sample EWB 071 yield a lower intercept age of 18.95 $\pm 2.94 / 3.04$

367 Ma (MSWD 2.1) in domain 1 (mostly cores; Figure 5B) and 14.45 \pm 0.63/0.85 Ma (MSWD 3.5) in 368 domain 2 (mostly rims; Figure 5C). Ages are quoted without and with systematic uncertainties 369 propagated respectively, following (Horstwood et al., 2016). Domain 1 is generally richer in 370 common $\mathrm{Pb}$ than domain 2.

372 Zircon

373 Thirty-nine U-Pb spots on zircon rims in sample EWB 071 (Figure 6A) yielded common-Pb374 corrected ${ }^{206} \mathrm{~Pb} /{ }^{238} \mathrm{U}$ dates between $26.6 \pm 5.0-14.6 \pm 0.3 \mathrm{Ma}$, with all but the oldest two 375 dates, and those with the largest uncertainties concentrating between $17.3 \pm 1.2-14.6 \pm 0.3$ 376 Ma (Figure 6B). Seventy-one zircon core analyses yielded a discordia array between $478.4 \pm$ $37716.5 \mathrm{Ma}$ and ca. $15 \mathrm{Ma}$ (not plotted). Of the Himalayan-aged (<30 Ma) growth zones, different $378 \mathrm{CL}$ responses match onto variations in $\mathrm{U}$ concentration and age. The CL-bright cores with lower $379 U$ concentrations (ca 80-600 ppm) in general contained higher common-Pb concentrations and 380 yielded older dates $(17.3 \pm 1.2$ to $15.3 \pm 0.4 \mathrm{Ma})$. The $\mathrm{CL}$-dark cores and rims with higher $\mathrm{U}$ 381 concentrations (ca. 800-2000 ppm) in general yielded younger dates (15.5 \pm 0.3 to $14.6 \pm 0.3$ $\mathrm{Ma}$ ) and had lower common-Pb concentrations. 

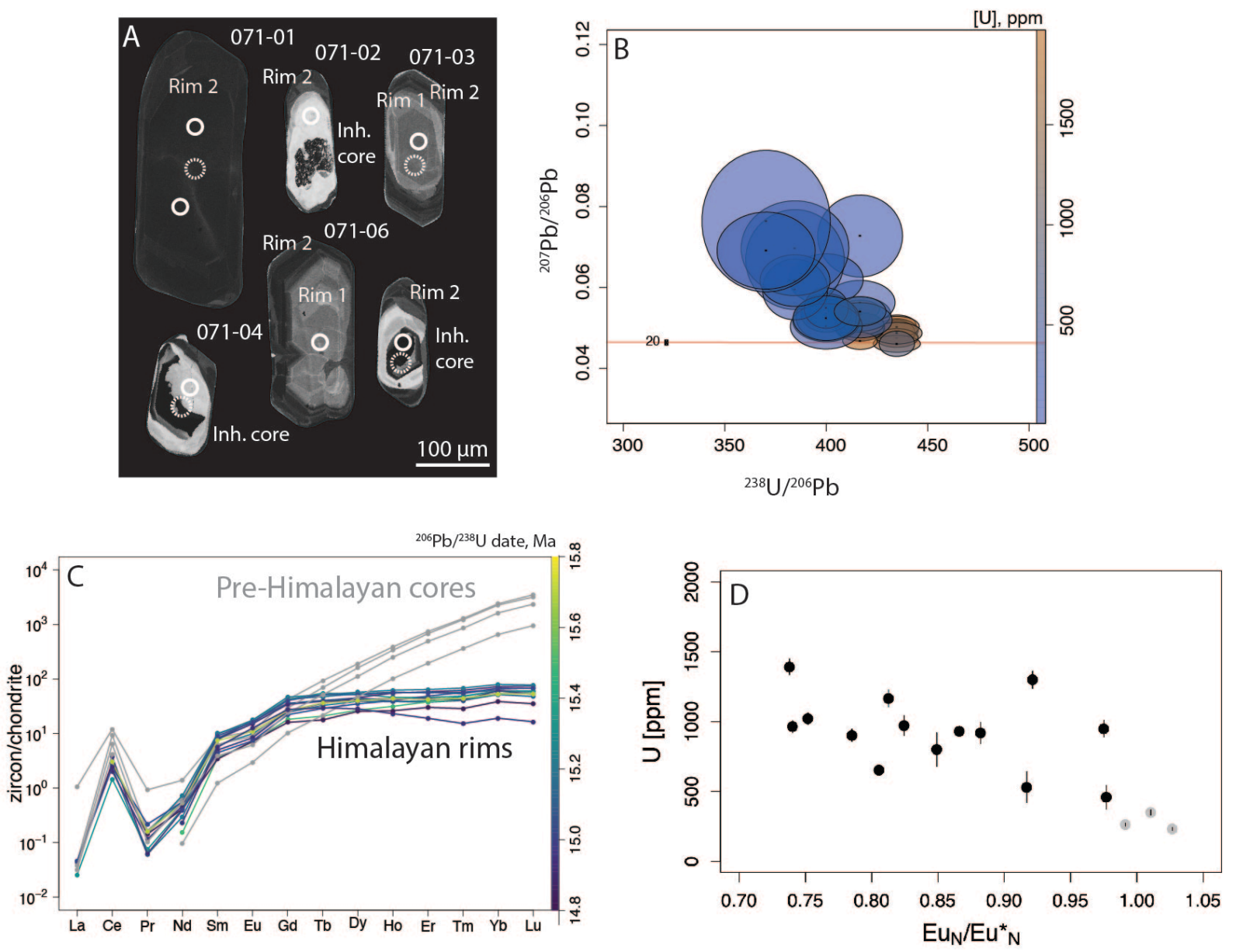

384 Figure 6. Zircon data in sample EWB 071. (A) Representative CL images of zircon grains. Solid 385 spots represent the U-Th-Pb analyses (GTF); dashed spots indicate the trace element analyses 386 (OU). (B) Tera-Wasserburg U-Pb plot with analyses coloured by U concentration. (C) Chondrite387 normalised rare earth element plot with Himalayan-aged zones coloured by ${ }^{206} \mathrm{~Pb} /{ }^{238} \mathrm{U}$ age. (D) 388 Plot of $U$ concentrations (measured at OU during trace element analysis) vs. $\mathrm{Eu}_{\mathrm{N}} / \mathrm{Eu}^{*}{ }_{\mathrm{N}}$.

390 Chondrite-normalised REE patterns for Himalayan-aged ( $<30 \mathrm{Ma}$ ) zircon rims in sample EWB 391071 (Figure 6C) show a positive Ce anomaly, a flat HREE profile and EuN/Eu* ${ }_{N}$ of 0.8-1.2.

$392 \mathrm{Eu}_{N} / \mathrm{Eu}^{*}{ }_{\mathrm{N}}$ values are correlated with $\mathrm{U}$ concentrations, with lower $\mathrm{Eu}_{N} / \mathrm{Eu}^{*}{ }_{N}$ in zones with higher $393 \mathrm{U}$ (Figure 6D). 
394 Thirty two spots on zircon rims in sample EWB 017x (Figure 7A) yielded ${ }^{206} \mathrm{~Pb} /{ }^{238} \mathrm{U}$ dates

395 between $25.4 \pm 1.8-13.5 \pm 0.7 \mathrm{Ma}$ (Figure $7 \mathrm{C}$ ), with all but four analyses yielding a cluster of

396 dates between $17.5 \pm 1.8-13.5 \pm 0.7 \mathrm{Ma}$. Older zones yield lower $\mathrm{U}$ concentrations whereas

397 the younger zones yield a greater range of $U$ concentrations.

$398 \mathrm{U}-\mathrm{Pb}$ age results for samples EWB 063, 064 and RBC are summarised in Table 1.
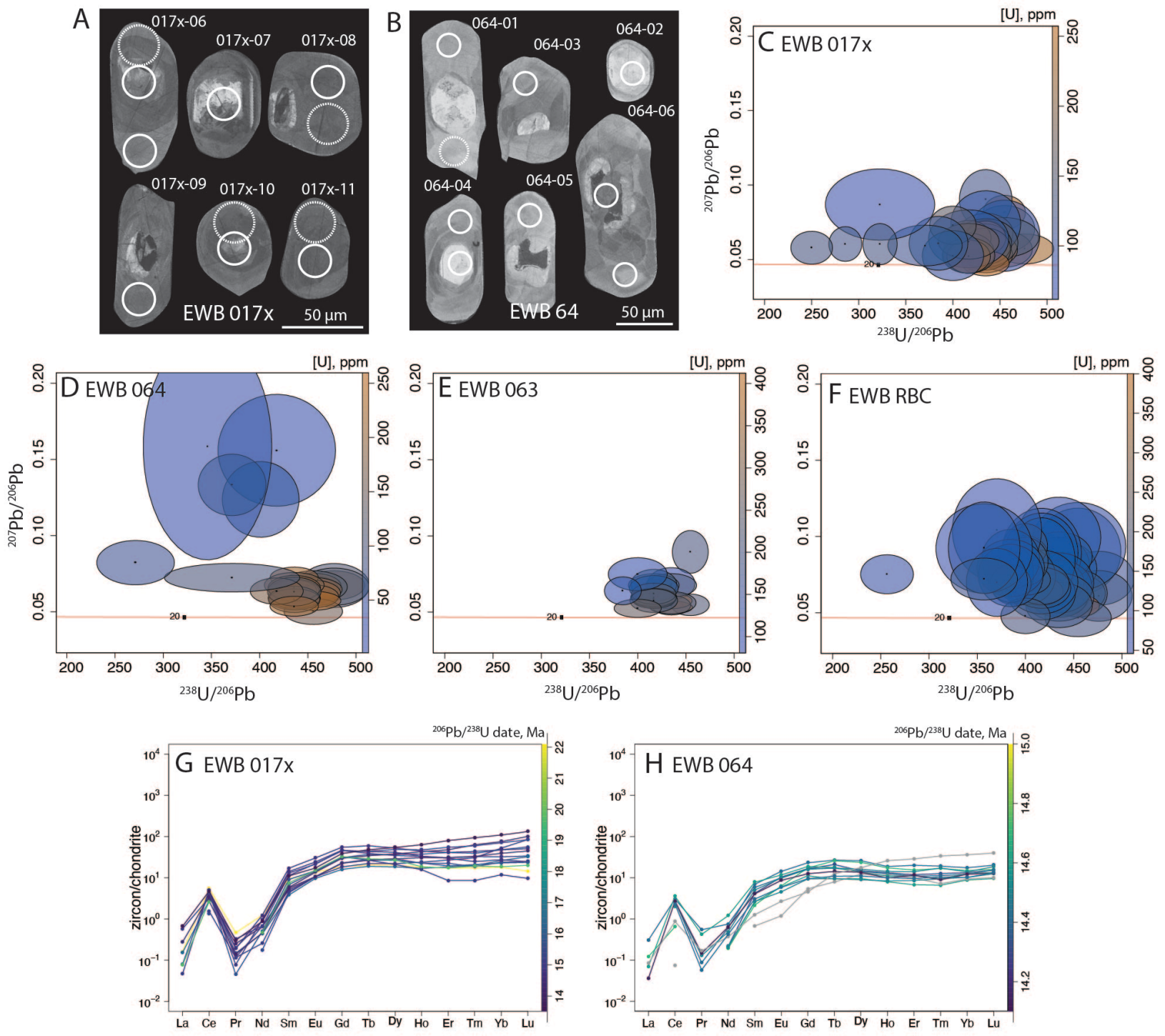
400 Figure 7. Zircon data for samples EWB 017x, 064, 063 and RBC. (A and B) Representative CL

401

402

403

404

405

406

407

408

\begin{tabular}{|c|c|c|c|c|c|}
\hline Sample & $\begin{array}{c}\text { \# spots on } \\
\text { rims }\end{array}$ & Max age & Min age & $\begin{array}{c}\text { \# spots on } \\
\text { cores }\end{array}$ & Core ages \\
\hline & & (Ma) & (Ma) & & Discordia between 478.4 \pm 16.5 and \\
EWB 071 & 39 & $26.6 \pm 5.0$ & $14.6 \pm 0.3$ & 71 & Ca. 15 Ma \\
\hline EWB 017x & 32 & $25.4 \pm 1.8$ & $13.5 \pm 0.7$ & 12 & Discordant \\
\hline EWB 063 & 29 & $16.3 \pm 0.6$ & $13.3 \pm 0.4$ & 10 & Discordant \\
\hline EWB 064 & 21 & $22.8 \pm 2.6$ & $9.7 \pm 1.0$ & 16 & Discordant \\
\hline EWB RBC & 47 & $17.4 \pm 1.3$ & $13.2 \pm 1.0$ & 9 & \\
\hline
\end{tabular}
images of zircon grains from samples EWB 017x and 064. Solid spots represent the U-Th-Pb analyses (GTF); dashed spots indicate the trace element analyses (OU). (C to F) TeraWasserburg U-Pb plot with analyses coloured by $\mathrm{U}$ concentration; note the difference in $\mathrm{U}$ concentration scale between (C, D) and $(E, F)$. ( $G$ and $H$ ) Chondrite-normalised rare earth element plots for samples EWB 017x and 064 with Himalayan-aged zones coloured by ${ }^{206} \mathrm{~Pb} /{ }^{238} \mathrm{U}$ age.

Table 1: Zircon U-Pb age summary.
410

411

412

413

414

415

416

Chondrite-normalised REE patterns for Himalayan-aged ( $<30 \mathrm{Ma}$ ) zircon rims in samples EWB 017x and 064 record higher mean $\mathrm{Gd}_{N} / \mathrm{Yb}_{\mathrm{N}}$ and $\mathrm{Eu}_{\mathrm{N}} / \mathrm{Eu}^{*}{ }_{\mathrm{N}}$ than EWB $071\left(\mathrm{Gd}_{\mathrm{N}} / \mathrm{Yb}_{\mathrm{N}} 1.13\right.$ and 1.49 compared to $0.84 ; \mathrm{Eu}_{\mathrm{N}} / \mathrm{Eu}^{*}{ }_{\mathrm{N}} 0.99$ and 1.1 compared to 0.84 respectively), however the ranges recorded in each sample overlap between samples. All zircons record positive Ce anomalies, flat HREE profiles and $\mathrm{Eu}_{\mathrm{N}} / \mathrm{Eu}^{*}{ }_{\mathrm{N}}$ between 0.8-1.2. Ti concentrations are similar in EWB 017x and 071, between 7.6-2.3 ppm and 7.9-2.1 ppm respectively. Lower concentrations are found in EWB 064 (4.2-1.4 ppm). 
421 Garnet major element compositions are similar between samples and fairly homogeneous

422 across grains. Garnets are universally almandine-rich: 70\% alm, 20\% grs, 10\% pyp and minor

423 sps (Supplementary Table 1, Figures 8C and 8I). Strong major element zoning was only

424 recorded in garnets in sample EWB017x (Figure 8F).

\section{EWB 071}

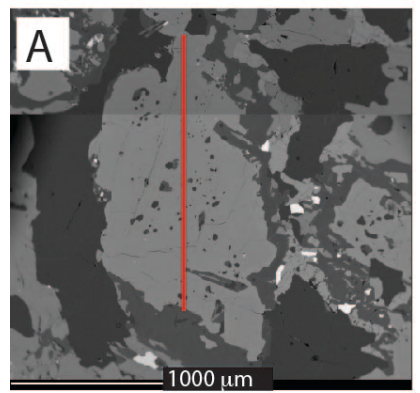

EWB 17x

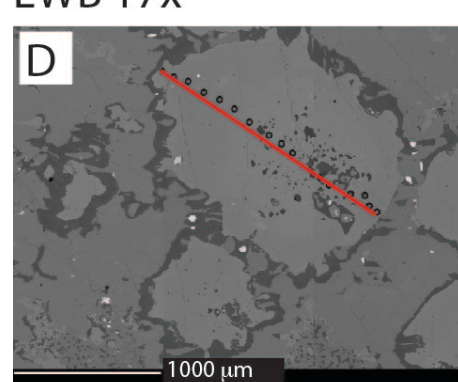

EWB 064

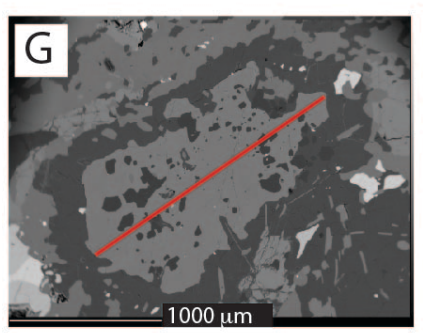

B
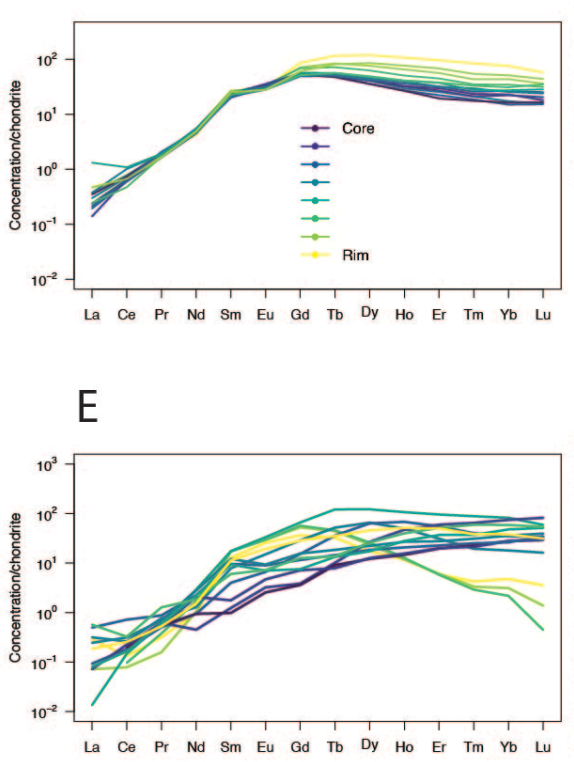

$\mathrm{H}$

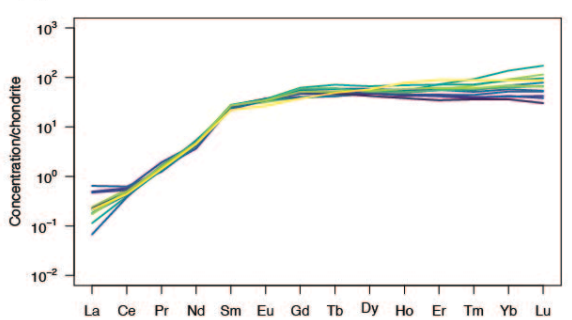

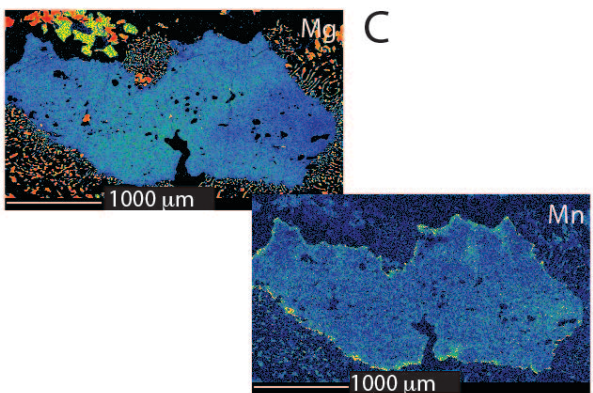

$\mathrm{F}$

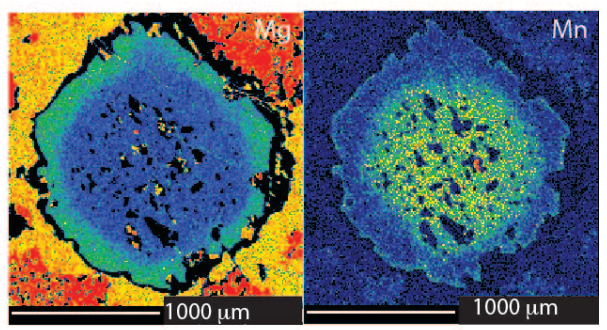

I
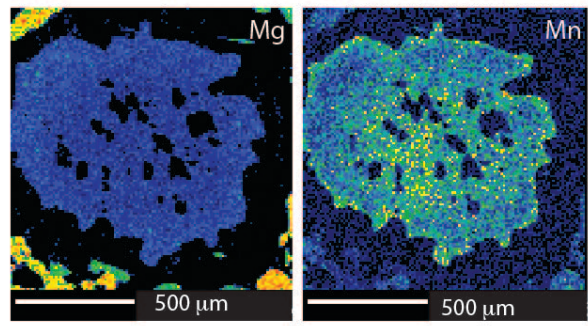

Figure 8: Garnet BSE images, trace element data and element maps for samples EWB 071, 017x 427 and 064.

429 Garnets in samples EWB 071, 017x and 064 show flattened HREE patterns and, generally a lack 430 of, or small, Eu anomaly $\left(\mathrm{Eu}_{N} / \mathrm{Eu}^{*}{ }_{\mathrm{N}} 0.63-1.48\right)$ (Figure 8B,E,G). HREE and $\mathrm{Y}$ concentrations in 
431 EWB 071 and 064 increase from (geographic) core to (current remaining) rim. Garnets in 432 sample EWB 071 and 064 record only minor core-rim changes in trace element concentrations.

433 Two aliquots of garnet from sample EWB 064 yielded an isochron that provided a date of $15.3 \pm$ $434 \quad 0.3 \mathrm{Ma}$; MSWD 3.5 (Figure 9). Lu-Hf isotopes measured in garnets from samples EWB071 and 435 EWB17x failed to produce an isochron.

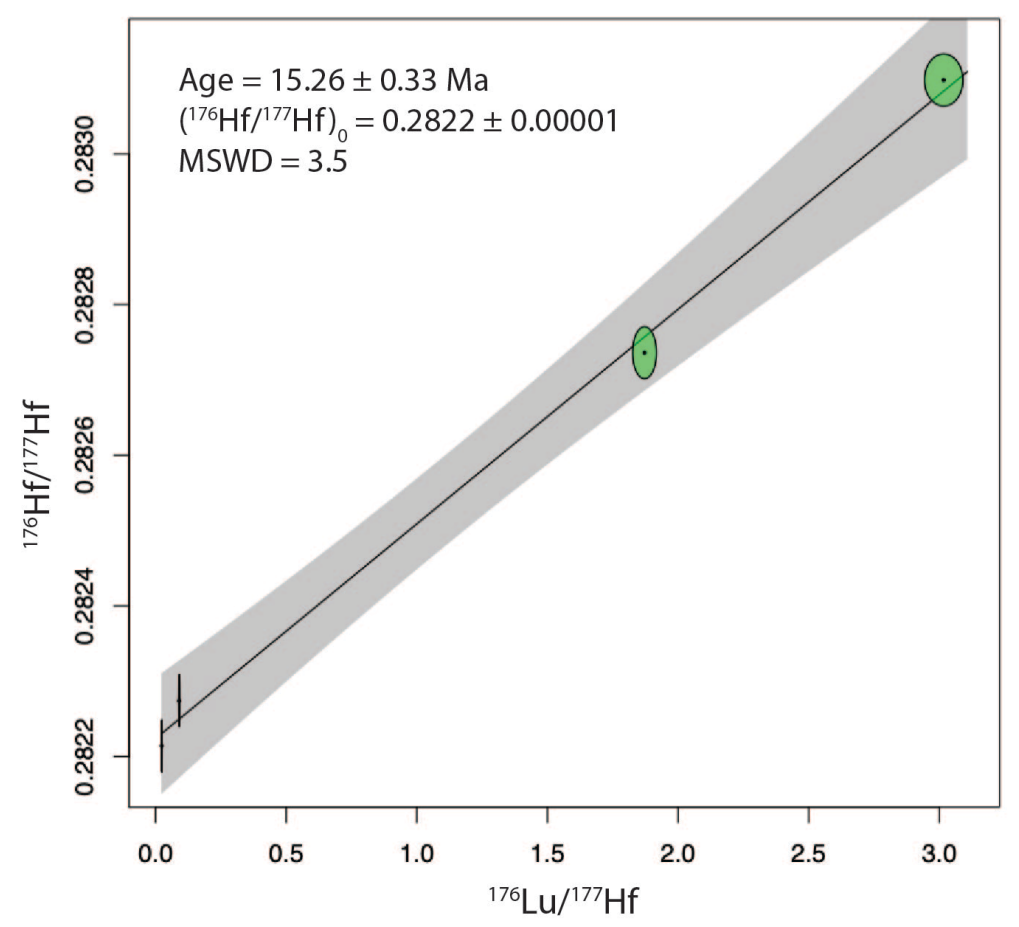

436

437 Figure 9. Garnet Lu-Hf isochron for sample EWB 064.

440 Temperatures calculated using the Ti-in-zircon thermometer (Ferry \& Watson, 2007) for Ti 441 concentrations in the Himalayan-aged zircon rims dated in this study lie between $618-724^{\circ} \mathrm{C}$ in 442 EWB 071, 624-721 ${ }^{\circ} \mathrm{C}$ in EWB 017x and 588-670 $\mathrm{C}$ in EWB 064. 
443 Average P-T calculations for the observed granulite-facies mineral assemblages in metabasic 444 samples EWB 071, EWB 064 and EWB 017x yield temperatures between $790 \pm 70^{\circ} \mathrm{C}$ to $890 \pm$ $44560^{\circ} \mathrm{C}$ and pressures of $0.9 \pm 0.1$ to $1.0 \pm 0.1 \mathrm{GPa}$ (Table 3, Figure $10 \mathrm{~A}$ ).

446 Table 3: Average pressure and temperature calculation results.

\begin{tabular}{|c|c|c|c|c|c|c|c|c|c|}
\hline Smpl & $\begin{array}{l}\text { Calculation } \\
\text { assemblage }\end{array}$ & $\begin{array}{c}X- \\
\mathrm{H}_{2} \mathrm{O}\end{array}$ & $\mathbf{T}$ & $\begin{array}{l}\text { Un- } \\
\text { cer- } \\
\text { tain- } \\
\text { ty }\end{array}$ & $\mathbf{P}$ & $\begin{array}{l}\text { Un- } \\
\text { cer- } \\
\text { tain- } \\
\text { ty }\end{array}$ & $\begin{array}{l}\text { Cor } \\
* *\end{array}$ & $\underset{* * *}{\mathbf{N}}$ & $\begin{array}{l}\text { Excl. end- } \\
\text { members }\end{array}$ \\
\hline & & & ${ }^{\circ} \mathrm{C}$ & $\begin{array}{l}{ }^{\circ} \mathrm{C} \\
1 \mathrm{SD}\end{array}$ & $\mathrm{GPa}$ & $\begin{array}{l}\mathrm{GPa}, \\
1 \mathrm{SD}\end{array}$ & & & \\
\hline $\begin{array}{l}\text { EWB } \\
017 x \\
\text { (core) }\end{array}$ & $\begin{array}{c}\text { Bt, PI (i*), Cpx } \\
\text { (i), Amp (i), Grt } \\
\text { (core), Qz, Rt, } \\
\text { Ttn, Ilm, } \mathrm{H}_{2} \mathrm{O}\end{array}$ & 1 & 825 & 48 & 1.01 & 0.09 & 0.47 & 11 & $\mathrm{IIm}$ \\
\hline $\begin{array}{l}\text { EWB } \\
017 x \\
\text { (rim) }\end{array}$ & $\begin{array}{c}\text { Bt, Pl, Cpx, } \\
\text { Amp, Grt (rim), } \\
\text { Opx, Qz, Ilm, } \\
\mathrm{H}_{2} \mathrm{O}\end{array}$ & 0.25 & 887 & 58 & 0.94 & 0.11 & 0.52 & 10 & \\
\hline $\begin{array}{c}\text { EWB } \\
064\end{array}$ & $\begin{array}{c}\text { Bt, } \mathrm{Pl}, \mathrm{Cpx} \\
\text { Amp, Grt, Opx, } \\
\mathrm{Qz}, \mathrm{Ilm}, \mathrm{H}_{2} \mathrm{O}\end{array}$ & 0.11 & 808 & 55 & 0.86 & 0.11 & 0.5 & 10 & \\
\hline $\begin{array}{c}\text { EWB } \\
071\end{array}$ & $\begin{array}{c}\text { Bt, PI, Cpx, } \\
\text { Amp, Grt, Opx, } \\
\text { Qz, Rt, Ttn, } \mathrm{H}_{2} \mathrm{O}\end{array}$ & 0.5 & 786 & 65 & 0.93 & 0.11 & 0.38 & 9 & Jd, Ttn \\
\hline
\end{tabular}

$*(i)=$ inclusion in garnet

** Correlation coefficient between $\mathrm{P}$ and $\mathrm{T}$, where 1 = perfect correlation $* * * \mathrm{~N}=$ number of independent reactions between end members used for each calculation 

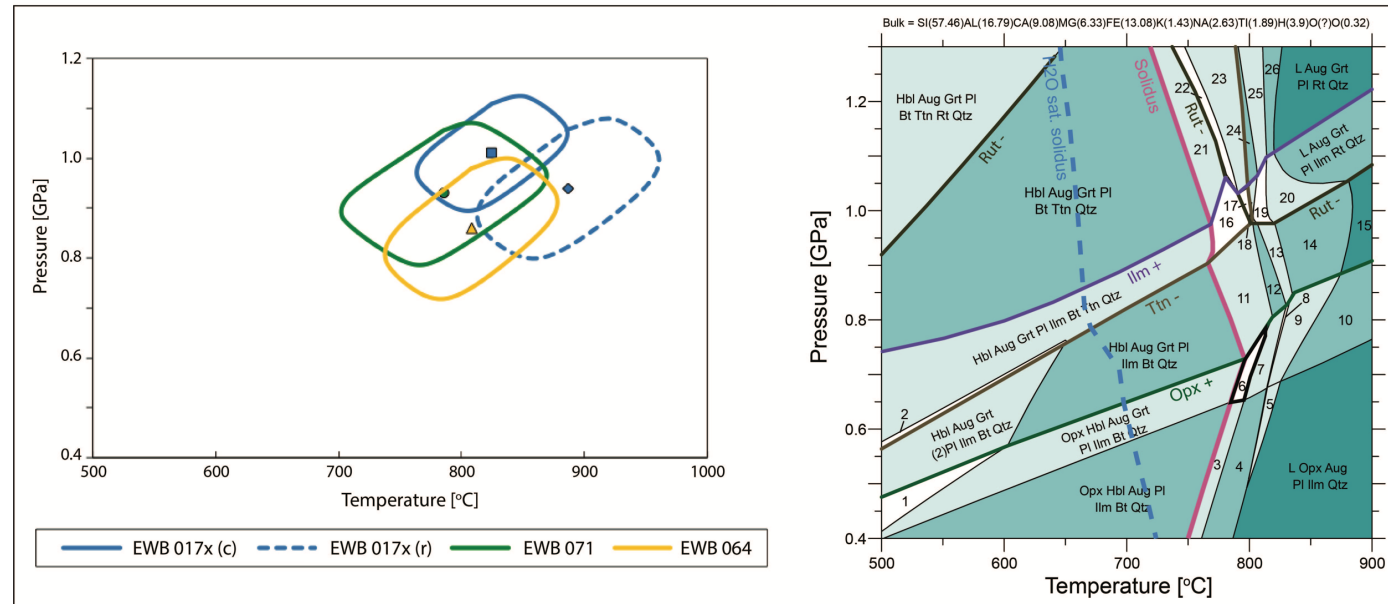

1- Opx Hы Grt Aug (2)PI IIm Bt Qtz - Hbl Aug Grt (2)P IIIm Bt Ttn Qtz 4- L Opx Aug PI IIm Bt Qtz 5 - L Opx Aug Grt (2)PI IIm Qtz - L Opx Hbl Aug Grt Pl IIIm Bt Qtz - L Opx Aug Grt (2)PI IIm Qtz 10- L Opx Aug Grt PI IIm Qtz

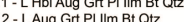
13. LAug Grt(2)Pl Im Bt Otz 14- LAug Grt (2)PI IIIm Qtz LAug Grt PI IIIm Qtz 列 8 - LAug Grt PI IIm Bt Rt Qtz - LAug Grt (2)PI IIm Bt Rt Qtz 21- L Hbl Aug Grt PI Bt Ttn Qtz 22 - L Hbl Aug GI PI Pt Tt Tt Rt Qtz 23- LAug Grt Pl Bt Ttn Rt Qtz (25 26- LAug Grt (2)PPI Rt Otz

Figure 10: A: PT results calculated using avPT function in THERMOCALC (Powell \& Holland, 1988) for samples EWB 071, 064 and 017x. B: Pseudosection calculated for EWB 071 using Theriak Domino (de Capitani \& Petrakakis, 2010) showing the preserved granulite-facies assemblage in field 6 (black outline), constrained by melt-in, orthopyroxene-in, garnet-out and biotite-out reactions. The solidus for water concentrations determined by binary $\mathrm{T}-\mathrm{X}_{\mathrm{H} 2 \mathrm{O}}$ diagrams is shown in pink and the water-saturated solidus is shown in blue. Qtz = quartz, all other abbreviations follow (Whitney \& Evans, 2010).

The pseudosection for EWB 071 (Figure 10B) is constrained along the temperature axis by the water-saturated solidus (dashed blue line in Figure 10B) and the biotite-out reaction, since a small amount of both biotite and former melt (now suggested by Qtz-PI-Kfsp assemblages) are preserved in EWB 071. The solidus was calculated on the assumption that melting under these conditions was driven primarily by biotite dehydration reactions, e.g. (Forshaw et al., 2019; Hartel \& Pattison, 1996; Patiño Douce \& Beard, 1995). The observed pervasive high-pressure granulite-facies overprint, represented by Grt $+\mathrm{Cpx}+\mathrm{Opx}+\mathrm{PI}+\mathrm{Amp}+\mathrm{Bt}+\mathrm{Qtz}+\mathrm{IIm}+\mathrm{Melt}$ (field 6 in Figure 10B), is constrained in the model at $\sim 775^{\circ} \mathrm{C}$ and $\sim 6.5-8 \mathrm{kbar}$. 
467

468

469

470

471

472

473

474

475

476

477

478

479

480

481

482

483

484

485

486

487

488

489

490

491

492

493

494

\section{Discussion}

In general the metabasite samples from NW Bhutan yield a tight clustering of zircon dates centred around $\sim 15 \mathrm{Ma}$, consistent with previous studies (Grujic et al., 2011a), though zircon in EWB 071 records two episodes of growth at $17.3 \pm 1.2$ to $15.3 \pm 0.4 \mathrm{Ma}$ and $15.5 \pm 0.3$ to $14.6 \pm$ $0.3 \mathrm{Ma}$ separable by $\mathrm{CL}$ response and U-concentration with age. Allanite cores and garnet also yield broadly overlapping dates around $15 \mathrm{Ma}$. However, our new petrographic observations and trace element, isotopic and pressure-temperature data allow us to distinguish between geochronometer growth under eclogite and granulite faces conditions. Specifically, the discovery of allanite and the chemical history recorded within it, are key to constraining the timing of the eclogite to granulite transition. Together these data shed new light on key parts of the metamorphic evolution of this enigmatic and deep-rooted part of the Himalayan orogen.

Much of our petrochronological interpretation relies on the assumption that the lack of a negative Eu anomaly $\left(\mathrm{Eu}_{\mathrm{N}} / \mathrm{Eu}^{*}{ }_{\mathrm{N}}\right)$ in allanite, garnet and zircon suggests growth in a plagioclasefree assemblage, and thus growth under eclogite facies conditions (Hinton \& Upton, 1991; Murali et al., 1983; Rubatto, 2002). The small EuN/Eu* ${ }_{\mathrm{N}}$ measured in most zircons may be inherited from the host rock (Hermann et al., 2001; Schaltegger et al., 1999) or may indicative that plagioclase is starting to enter the assemblage across the eclogite to granulite facies transition. The petrology of these samples suggests that they remained reduced throughout their metamorphic evolution and therefore that high $\mathrm{Eu}^{2+} / \mathrm{Eu}^{3+}$ should be expected.

\section{Allanite}

Petrographic observations, chemical zoning, U-Pb isotopic compositions (and thus age) and thermobarometric calculations all place constraints on allanite growth. In sample EWB 071 allanite is typified by relatively Ca-, and Al-enriched and REE-depleted (domain 1) cores and relatively REE, Th, Fe, Mg and Ti-enriched (domain 2) rims (Figure 4). This is inverse to the prograde zoning commonly reported for allanite in eclogites, which is typified by REE-enriched allanite cores overgrown by clinozoisite/epidote rims (Airaghi et al., 2019; Janots et al., 2007, 2008, 2009; Smye et al., 2011; Spear, 2010; St-Onge et al., 2013). Such inverse zoning has 
previously been reported only in heavily metasomatised garnet-amphibolite migmatites, with LREE-enriched rims attributed to influx of externally-derived REE-enriched fluids (Sorensen, 1991). In EWB 071 (occasionally) and EWB 064 (commonly), allanite is associated with patches and bands of felsic minerals; these features have the texture, mineralogy and appearance of "leucosome" or former melt. Embayments that crosscut both allanite domains are infilled by fingers of quartz and feldspar, further suggesting the presence of melt around the time of allanite formation.

The presence of rutile inclusions and the lack of a negative Eu anomaly $\left(\mathrm{Eu}_{N} / \mathrm{Eu}^{*}\right)$ in the domain 1 cores of the large allanite porphyroblasts (Figure 5A) suggests they grew in a feldsparabsent assemblage and thus under eclogite-facies conditions. The domain 2 composition is associated with three symplectitic associations: with anorthite on the rims of the large porphyroblasts (Figure 2D,E; Figure 4 grain G2) or with ilmenite or clinopyroxene on smaller, fully-symplectised grains (Figure 21; Figure 4 grain G7).

Three observations and datasets suggest that domain 2 grew at lower pressures than domain 1. Firstly, domain 2 records a significant negative Eu anomaly, suggesting growth in the presence of plagioclase. Secondly, the intergrowth of domain 2 allanite with ilmenite suggests growth at pressures lower than the rutile stability field (Angiboust \& Harlov, 2017). Finally, the intergrowth of a domain 2 grain with symplectites of ilmenite + clinopyroxene, suggests growth during the breakdown of titanite, c.f. (Marsh \& Smye, 2017).

Domain 2 rims on the large allanite porphyroblasts typically infill and mantle embayed domain 1 cores. Here, domain 2 is associated with anorthite, suggesting a reaction that involves domain 1 reacting to domain $2+$ anorthite. The overall volume reduction in allanite as a result of this reaction favours the preferential partitioning of REE + Fe into the newly formed allanite and Ca + Al into the newly formed anorthite. The association of allanite with regions of more felsic mineralogy in the rock (interpreted as the presence of melt) and the strongly embayed presentation of both allanite domains suggests that melt may have mediated the dissolution of domain 1 and the formation of domain 2. 
522 Plotting the allanite $\mathrm{U}-\mathrm{Pb}$ data by textural position (domains 1 and 2) yields two arrays which, 523 when considering the data without systematic uncertainties, are just outside of uncertainty of 524 each other, $18.95 \pm 2.94 \mathrm{Ma}$ and $14.45 \pm 0.63 \mathrm{Ma}$, respectively (Figure 5B,C). The allanite dates 525 can be compared without systematic uncertainties as they were measured in a single session, 526 but systematic uncertainties are required when comparing with the other geochronological 527 constraints. Previous studies suggest that allanite grains $>20 \mu \mathrm{m}$ wide retain radiogenic $\mathrm{Pb}$ at 528 temperatures $>700^{\circ} \mathrm{C}$ for $>10 \mathrm{Ma}$ (McFarlane, 2016; Oberli et al., 2004; Smye et al., 2014) and 529 can thus preserve evidence for growth across multiple metamorphic stages or during different 530 metamorphic events. We therefore interpret the allanite U-Pb dates in our samples as 531 recording the timing of allanite crystallisation.

532 Semi-quantitative P-T constraints on allanite growth across the eclogite-granulite transition are 533 provided by experimental data on zoisite breakdown and by the results of the pseudosection modelling for sample EWB 071. There are currently no experimental constraints on the stability 535 of REE-rich allanite, but experimental data for LEE-poor zoisite suggest that zoisite breaks down 536 during decompression and/or heating via the reaction zoisite + kyanite + quartz --> anorthite + $537 \mathrm{H}_{2} \mathrm{O}$ at $>750-800^{\circ} \mathrm{C}$ for pressures of $\sim 1.0-1.1 \mathrm{GPa}$ and $>600-750^{\circ} \mathrm{C}$ for pressures of $\sim 0.7-1.0 \mathrm{GPa}$ 538 (Matthews \& Goldsmith, 1984). Assuming that allanite reacts in a similar way at somewhat 539 similar conditions, these results suggest that breakdown of domain 1 allanite to domain 2 540 allanite + anorthite occurred at temperatures of ca $750^{\circ} \mathrm{C}$ during decompression from $\mathrm{P}>10$ 541 kbar.

542 Furthermore, the pseudosection calculated for EWB 071 (Figure 10B) indicates that at T 700$543750^{\circ} \mathrm{C}$, titanite is only stable at $\mathrm{P}>0.8-0.9 \mathrm{GPa}$. The association of domain 2 allanite with 544 ilmenite + clinopyroxene, which itself suggests the breakdown of titanite (Marsh and Smye 545 2017), provides further evidence that domain 2 allanite grew during decompression at $P<0.9$ $546 \mathrm{GPa}$ at $\mathrm{T} \sim 750^{\circ} \mathrm{C}$.

547 Taken together, the petrographic observations, trace element data and isotopic data suggest 548 that domain 1 allanite grew under eclogite facies conditions (T 650 ${ }^{\circ} \mathrm{C}, \mathrm{P}>1.7 \mathrm{GPa}$ ) at $18.95 \pm$ $5493.04 \mathrm{Ma}$ and domain 2 allanite grew under granulite-facies conditions $\left(\mathrm{T} 750^{\circ} \mathrm{C}, \mathrm{P}<0.9 \mathrm{GPa}\right)$ at 
$14.45 \pm 0.85 \mathrm{Ma}$ (systematic uncertainties included here). The paucity of radiogenic lead in the allanite cores for both datasets precludes a more precise constraint on the timing of the eclogite to granulite facies transition. However the data are overall compatible with previous conclusions of a relatively geologically recent and relatively rapid (both in Himalayan terms) eclogite- to granulite-facies transition in these Eastern Himalayan lower orogenic crustal rocks (Grujic et al., 2011a; Warren et al., 2011).

\section{Zircon}

The chemical zoning and $\mathrm{U}-\mathrm{Pb}$ dates documented in zircon provide information that complements and supplements the allanite record. Zircon in sample EWB 071 yielded two distinct populations of Himalayan-aged cores and rims (17.3 \pm 1.2 to $15.3 \pm 0.4 \mathrm{Ma}$ and $15.5 \pm$ 0.3 to $14.6 \pm 0.3 \mathrm{Ma}$ ) separable by $\mathrm{CL}$ response, U-concentration and age. Zircon in sample EWB 017x and 064 also records an evolution towards $U$ enrichment from ca. 15.5 Ma (Figures 6B, 7C, 7D). Together, these trends imply the breakdown of a U-enriched phase in these samples during zircon growth. Candidate phases in the eclogite-facies assemblage include detrital/inherited zircon (the pre-Himalayan cores contain concentrations of 60 - 7490 ppm U), allanite (up to 0.2 weight $\% U$ ), apatite (U concentrations in these samples unknown), rutile (U concentrations in these samples unknown) and garnet ( $<0.3 \mathrm{ppm} U$ but volumetrically significant (Degeling et al., 2001).

Textural evidence for the dissolution of pre-Himalayan zircon cores is shown by truncation of features in the $C L$ images by younger (Himalayan-aged) overgrowths (Figures 6A, 7A, 7B). However, the textural relationships between the older CL-bright Himalayan-aged cores and the younger CL-dark Himalayan-aged rims in EWB 071 do not suggest extensive dissolution between those growth episodes, so dissolution of pre-Himalayan zircon may not fully explain the documented enrichment in $U$ at this time. Allanite, however, exhibits significant textural evidence for dissolution following the growth of the porphyroblast cores and therefore could be a viable source of $U$ for the youngest population of zircon, at least in samples EWB 071 and 064. 
578 The two Himalayan zircon rim populations in EWB 071 also have distinctive Eu concentration 579 signatures. The older, lower U, CL-bright rim-1 population shows an $\mathrm{Eu}_{N} / \mathrm{Eu}^{*}{ }_{\mathrm{N}}$ of ca. 1, i.e. no 580 anomaly, whereas the younger, higher- $U, C L-d a r k$ rim-2 population shows a trend towards a 581 more negative EuN/Eu*N (Figure 6D). These data suggest a plagioclase-absent (eclogite-facies)

582 assemblage during rim-1 growth and a plagioclase-present (granulite-facies) assemblage during 583 rim-2 growth. Overall, the data suggest that zircon in sample EWB 071 records growth between $58417.3 \pm 1.2$ to $15.3 \pm 0.4 \mathrm{Ma}$ during eclogite-facies conditions or the transition between eclogite585 and granulite-facies conditions (when zircon was not competing for Eu with plagioclase 586 (Rubatto, 2002)), and between $15.5 \pm 0.3$ to $14.6 \pm 0.3$ Ma under granulite-facies conditions. 587 These geochronological and geochemical data are consistent with the allanite record.

588 Zircon in samples EWB 017x and EWB 064 yield overlapping age populations with EWB 071, and 589 show a similar trend in increasing $U$ concentrations over time. However changes in their $590 \mathrm{Eu}_{\mathrm{N}} / \mathrm{Eu}^{*}{ }_{\mathrm{N}}$ signatures with $\mathrm{U}$ (as a proxy for age, since the data were collected in different 591 analytical sessions) are less clear. Their $\mathrm{Eu}_{\mathrm{N}} / \mathrm{Eu}^{*}{ }_{\mathrm{N}}$ signatures are suggestive of growth in garnet592 present, plagioclase-absent assemblages.

594 Garnet

595 The garnet in all of the studied samples is heavily corroded, and preserves little major element 596 zoning. Sample EWB 017x contains garnets that preserve inconclusive REE zoning; the dataset 597 may reflect mixing of garnet with inclusions. Samples EWB 071 and 064 contain garnets that 598 record increasing concentrations of HREE and $Y$ towards the current rim, opposite to what 599 would be expected for Rayleigh fractionation during growth, e.g. (Otamendi et al., 2002) or for 600 diffusion-limited uptake of trace elements, e.g. (Skora et al., 2006). Instead, such increases are 601 consistent with increased supply of elements during the breakdown of other HREE-and Y602 bearing phases such as zircon, allanite or titanite. The lack of concomitant increase in $\mathrm{Zr}$ or $\mathrm{Ti}$ 603 towards the rim suggests that the garnet rims may be recording the release of $Y$ and HREE from 604 allanite rather than zircon or titanite. 
605 In EWB 071 and 064, the $\mathrm{Eu}_{\mathrm{N}} / \mathrm{Eu}^{*}{ }_{\mathrm{N}}$ in garnet trend towards more negative values towards the $606 \mathrm{rim}$, from a value of around 1 in the core. This suggests that the garnet core grew in the 607 absence of plagioclase (indicative of eclogite-facies conditions) whereas the rims grew in the 608 presence of increasing modal proportions of plagioclase.

609 Garnets in EWB 064 are heavily corroded, and we interpret the remnants to be spatially skewed 610 towards the original garnet core. The remnants of the rims record higher Lu concentrations 611 than the cores (Figure $8 \mathrm{H}$ ). The calculated garnet $\mathrm{Lu}-\mathrm{Hf}$ date $15.3 \pm 0.3 \mathrm{Ma}$ is therefore an 612 average of both core and rim that could be skewed towards a core age by garnet volume, or 613 towards a rim age by higher Lu concentrations. The age is consistent with the ages calculated 614 from domain 2 allanite and zircon but straddles the timing of the transition from eclogite to granulite facies conditions suggested by the allanite and zircon ages.

\section{Pressure-temperature-time evolution}

618 The rich micro-textural and chemical record in metabasite samples such as EWB 071 allow the detailed P-T-t evolution of some of the most deeply exposed parts of the eastern Himalayan orogen to be constrained in some detail, c.f. (Groppo et al., 2007). The main texture in the studied samples that is indicative of precursor HP (eclogite-facies) metamorphism is the association of clinopyroxene + garnet + quartz + rutile with no associated plagioclase. This texture has been described from metabasite samples throughout the eastern Himalaya and in -

624 analogous terranes found in other orogenic belts (Anderson \& Moecher, 2007; Groppo et al., 2007; Kellett et al., 2014; Möller et al., 2015; O’Brien \& Rötzler, 2003).

626 In EWB 071, the timing of mineral crystallisation under eclogite facies conditions is constrained

627 by the domain 1 cores of the large allanite porphyroblasts (18.95 $\pm 3.04 \mathrm{Ma})$ and the domain 1 628 (inner) rims preserved in some zircon grains (17.3 $\pm 1.2-15.3 \pm 0.4 \mathrm{Ma}$; Figure 11$)$. The core 629 domains in allanite, zircon and garnet preserve HREE and $\mathrm{Eu}_{\mathrm{N}} / \mathrm{Eu}^{*}{ }_{\mathrm{N}}$ signatures that suggest 630 synchronous growth without competition for Eu with plagioclase (Rubatto, 2002). Constraints 631 on the absolute temperature and pressure conditions experienced in the eclogite facies are 
632 difficult to quantify due to pervasive chemical re-equilibration during subsequent heating and 633 decompression.

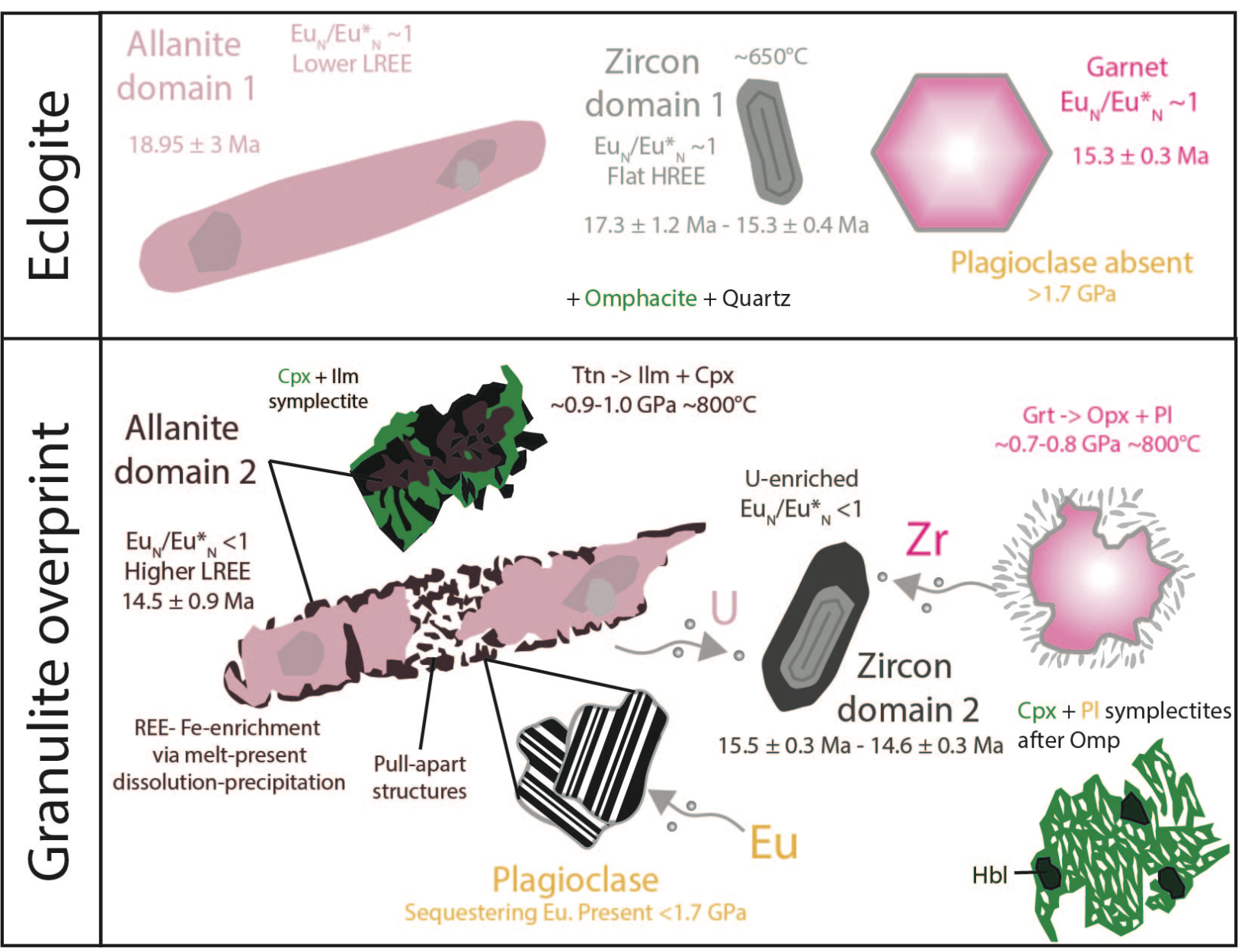

Figure 11. Summary of petrochronological observations and interpretations for sample EWB 071 (garnet dates from EWB 064; see text for discussion). Minerals are drawn for clarity, not to scale.

P-T constraints on the eclogite facies conditions experienced by the NW Bhutan samples remain

640 somewhat imprecise due to the lack of preservation of related major element chemical

641 signatures. Temperatures calculated from Ti-in-zircon concentrations (Ferry \& Watson, 2007) in

642 Himalayan-aged zircon zones lie between $620-720^{\circ} \mathrm{C}$ for samples EWB 071 and $017 x$ and between $590-670^{\circ} \mathrm{C}$ for EWB 064 , identical to those reported from a previous study of the same 
644 region (Grujic et al., 2011b). Calculations in Theriak-Domino suggest that omphacite with composition $\mathrm{Jd}=0.2$, c.f. (Y. Wang et al., 2017) is only stable at $\mathrm{P}>0.16-0.17 \mathrm{GPa}$ at $\mathrm{T}>650^{\circ} \mathrm{C}$. This result provides an estimated minimum pressure for the eclogite-facies conditions experienced by the NW Bhutan samples, and is similar to conditions estimated for eclogite-facies conditions for similar rocks in Ama Drime (Groppo et al., 2007; Y. Wang et al., 2017).

Granulite facies conditions, at higher temperatures and lower pressures than the eclogite facies conditions, are evidenced by the formation of multiple different symplectites (shown schematically on Figure 11): (i) Clinopyroxene + plagioclase \pm amphibole after omphacite, e.g. (Groppo et al., 2007); (ii) domain 2 allanite + plagioclase, ilmenite or clinopyroxene after domain 1 allanite at 14.6 \pm 0.1 Ma, e.g. (Matthews \& Goldsmith, 1984); (iii) clinopyroxene + ilmenite intergrowths after titanite, e.g. (Faryad et al., 2006, 2010; Marsh \& Kelly, 2017; Marsh \& Smye, 2017; O’Brien \& Rötzler, 2003), and (iv) orthopyroxene + plagioclase after garnet, e.g. (O’Brien \& Rötzler, 2003). All of these symplectites, many of which are also described from metabasite samples elsewhere in the eastern Himalaya, are suggestive of decompression at temperatures $>750^{\circ} \mathrm{C}$. Experimental data plus information from pseudosection modelling suggests that symplectite (i) forms at the highest pressures and (iv) at the lowest pressures (Figure 10). Subsequent cooling of all these samples must have been at a rate that was rapid enough to preserve allanite as well as the fine symplectites and thus prevent the attainment of textural equilibrium.

In addition to the symplectites, the second generation of the U-enriched zircon rims $(15.6 \pm 0.3$ - $14.6 \pm 0.3 \mathrm{Ma}$ ) and HREE-enriched garnet rims preserving increasing $\mathrm{Eu}_{\mathrm{N}} / \mathrm{Eu}^{*}{ }_{\mathrm{N}}$ values suggest growth in the presence of plagioclase: these garnet rims then subsequently being patchily replaced by the opx + plag symplectites. The patchy association of small domain 2 allanite grains with myrmekites interpreted as representing the former presence of melt indicates decompression associated with melting at this time.

In summary, petrographic observations and mineral data from metabasite samples in NW Bhutan, and especially sample EWB 071 suggest that evidence for the transition from eclogiteto granulite-facies metamorphism was geochemically captured by the growth of allanite and 
672 zircon. In total, the data suggest the following sequence of mineral growth: (i) Domain 1

673 allanite growth under eclogite facies conditions of $\mathrm{P}>0.16-0.17 \mathrm{GPa}$ and $\mathrm{T}>650^{\circ} \mathrm{C}$ at ca. $19 \mathrm{Ma}$.

674 (ii) Rim 1 zircon and garnet core growth under eclogite facies conditions but potentially during

675 decompression between 17-15.5 Ma. (iii) Synchronous dissolution-precipitation of domain 1

676 allanite, garnet, zircon rim 1 and rutile, and growth of REE-enriched domain 2 allanite rims and

677 allanite + anorthite, ilmenite or clinopyroxene symplectites plus the second generation of zircon

678 between 15.5-14 Ma. The combined suggested pressure-temperature-time path is shown in

679 Figure 12.

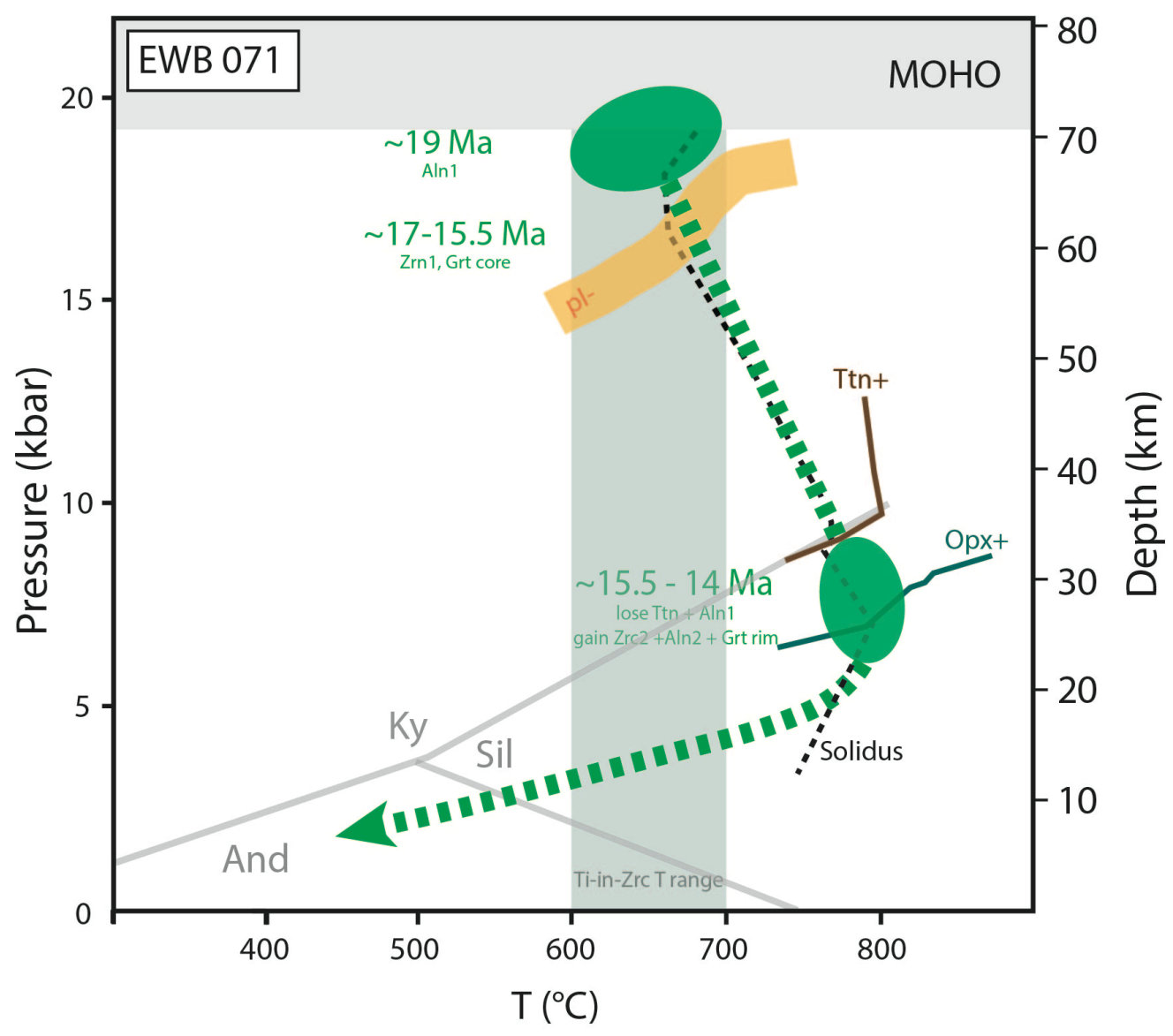

681 Figure 12. P-T-t summary of representative metabasite sample EWB 071 (garnet data from EWB 682 064). 
684 The Miocene zircon and allanite age populations are within the range of reported for other

685

686

687

688

689

690

691

692

693

694

695

696

697

698

699

700

701

702

703

704

705

706

707

708

709

710

711 granulitised eclogites throughout the eastern Himalaya (Kellett et al., 2014; Li et al., 2003; Lombardo et al., 2016; Y. Wang et al., 2017). The garnet in EWB 064 yields an age of $15.3 \pm 0.3$ $\mathrm{Ma}$, similar to the age of garnet growth in amphibolites in Ama Drime (15-14 Ma), but significantly younger than the timing of garnet growth recorded in granulitised eclogite samples recorded between ca. $38 \mathrm{Ma}$ (Kellett et al., 2014) and 20.7 $\pm 0.4 \mathrm{Ma}$ (Corrie et al., 2010).

\section{Implications for Himalayan evolution}

Despite the relative plethora of zircon and monazite data from granulitised eclogites in the eastern Himalaya and their host felsic rocks, linking time to the pressure-temperature evolution precisely has proven difficult and the interpretations much debated, e.g. (J.-M. Wang et al., 2021). This difficulty has led to different conflicting interpretations about what the ages mean with respect to eastern Himalayan tectonics. The discovery and analysis of allanite in the NW Bhutan samples allows the metamorphic evolution of these granulitised ecologites to be more tightly constrained. Our data suggest that between $19-15.5 \mathrm{Ma}$, the terrane hosting the granulitised eclogites in NW Bhutan experienced eclogite-facies metamorphism, recorded by the growth of garnet, domain 1 allanite and zircon rim 1 in plagioclase-free metabasitic assemblages. Between 15.5-14 Ma, decompression was captured by the growth of domain 2 allanite, zircon rim 2 and plagioclase-present symplectitic assemblages overprinting the eclogite facies assemblages. Previous studies document zircon and monazite in NW Bhutan migmatitic leucosomes and leucogranite bodies and sills recording ages between 15-11 Ma, interpreted as recording the timing of crystallisation of decompression-related anatectic melts (Hopkinson et al., 2020; Kellett et al., 2009; Montomoli et al., 2013; Warren et al., 2011). Rutile in felsic granulites from NW Bhutan record cooling through their closure temperature at ca. $11 \mathrm{Ma}$, suggesting cooling rates in the order of $40^{\circ} \mathrm{C} / \mathrm{Ma}$ (Warren et al., 2012).

This thermochronological history requires metamorphism in the deep orogenic crust prior to the growth of allanite at ca. $19 \mathrm{Ma}$, followed by rapid exhumation and heating. Previous studies have suggested a late-stage insertion of a 'tectonic plunger' (i.e. a ramp of cold rigid 
712 Indian lower-crust) into the lower-crust (Kellett et al., 2009; Warren et al., 2011). This

713 mechanism provides the additional surface-wards driving force required to exhume lower

714 orogenic crust that is neutrally buoyant compared to its surroundings (unlike, say, subduction-

715 related eclogites, see (O’Brien, 2019) for a succinct summary). Geophysical evidence for a ramp

716 of colder, stronger Indian basement crust beneath Tibet (Nábělek et al., 2009) coupled with

717 plate reconstructions that are suggestive of a slowing down of the India-Asia collision (Van

718 Hinsbergen et al., 2012) over the timescale of interest provide further supporting evidence of

719 this model.

720 The source of the heat input suggested by the $100-150^{\circ} \mathrm{C}$ rise in temperature between the 721 eclogite and granulite facies assemblages is still unclear. Hf-O data from zircons in nearby 722 anatectic granites suggest a purely crustal source for the melts, thus implying no advected heat 723 from mantle-derived melts at the time (Hopkinson et al., 2017). Temperatures estimated for 724 the eclogite-facies mineral assemblage have large associated uncertainties due to subsequent 725 chemical remobilisation. Temperatures estimated for the granulite-facies overprint may also be 726 over-estimated.

727 The metamorphic evolution of the NW Bhutan granulite-eclogites is somewhat cooler and 728 younger, and their exhumation apparently faster than the metamorphic evolution and 729 exhumation of similar rocks exposed further westwards in Sikkim, Ama Drime and in the 730 Everest region (Corrie et al., 2010; Cottle et al., 2009; Kellett et al., 2014; J.-M. Wang et al., 731 2021; Y. Wang et al., 2017). UHP metamorphism at $\mathrm{T}>900^{\circ} \mathrm{C}$ has been suggested from Opx-PI 732 thermometry for the Everest East region at 25-15 Ma followed by slow cooling at rates of 2$7333^{\circ} \mathrm{C} / \mathrm{Ma}$ (J.-M. Wang et al., 2021). These data suggest that the granulitised eclogites now 734 exposed in this region were metamorphosed to eclogite facies conditions at the lower levels of 735 over-thickened (ca. $60 \mathrm{~km}$ ) radioactive felsic crust and were then heated and exhumed during 736 east-west extension that thinned the orogenic lithosphere and allowed heat transfer from the 737 mantle. The heat source and tighter temperature constraints for the Bhutan granulite738 eclogites remain elusive and requires further study. Both could provide crucial information on 739 the geodynamic evolution of this part of the Himalayan orogen. 


\section{Conclusions}

742 The U-Pb geochronology, trace element signatures and microtextural record preserved in

743 allanite in two samples of granulitised eclogite captures a previously elusive record of the 744 timing of the eclogite to granulite facies transition in NW Bhutan. Our observations and data 745 suggest that allanite cores record growth under eclogite facies conditions $\left(>17 \mathrm{kbar} \sim 650^{\circ} \mathrm{C}\right)$ at 746 ca. $19 \mathrm{Ma}$, zircon inner rims and garnet cores record growth during decompression under 747 eclogite facies conditions at ca 17-15.5. Ma, and symplectitic allanite rims, garnet rims and 748 zircon outer rims record growth under granulite facies conditions at $\sim 9-6 \mathrm{kbar} ;>750^{\circ} \mathrm{C}$ at ca. 15$749 \quad 14.5 \mathrm{Ma}$. We think that this is the first recorded example of allanite recording a transition from 750 growth under eclogite facies to growth under granulite facies conditions, with preservation of 751 rare granulite-facies allanite likely facilitated by rapid exhumation and cooling. The breakdown 752 of titanite appears to have been coeval with the growth of the second generation of allanite, 753 thus providing a reaction mechanism for allanite growth under these conditions.

754 Our new observations and data confirm previous suggestions of rapid exhumation of deep 755 Himalayan crust during the Miocene at least in the eastern Himalaya. In combination with data 756 from similar rocks further westwards in the orogen, the new data suggest diachronous 757 exhumation of rocks metamorphosed at similar depths and potentially different exhumation 758 mechanisms.

\section{Acknowledgements}

761 EW thanks NERC and the Open University for PhD studentship funding through the CENTA 762 doctoral training partnership. Nyima Om and the field crew from Namsay Adventures are 763 thanked for excellent field logistical arrangements during two field seasons in Bhutan and Stacy 764 Philips for being a great field companion. Michelle Higgins and Kay Knight are thanked for their 765 assistance in the laboratories at the OU. Tom Knott is thanked for all his assistance with the XRF 766 analyses at the University of Leicester. 


\section{References}

769

770

771

772

773

774

775

776

777

778

779

780

781

782

783

784

785

786

787

788

789

790

791

792

Airaghi, L., Janots, E., Lanari, P., de Sigoyer, J., \& Magnin, V. (2019). Allanite petrochronology in fresh and retrogressed garnet-biotite metapelites from the Longmen Shan (Eastern Tibet). Journal of Petrology, 60(1), 151-176.

Anderson, E. D., \& Moecher, D. P. (2007). Omphacite breakdown reactions and relation to eclogite exhumation rates. Contributions to Mineralogy and Petrology, 154(3), 253-277.

Angiboust, S., \& Harlov, D. (2017). Ilmenite breakdown and rutile-titanite stability in metagranitoids: Natural observations and experimental results. American Mineralogist: Journal of Earth and Planetary Materials, 102(8), 1696-1708.

Chakungal, J., Dostal, J., Grujic, D., Duchêne, S., \& Ghalley, K. S. (2010). Provenance of the Greater Himalayan sequence: Evidence from mafic granulites and amphibolites in NW Bhutan. Tectonophysics, 480(1), 198-212.

Chaudhry, M. N., \& Ghazanfar, M. (1987). Geology, structure and geomorphology of upper Kaghan Valley, NW Himalaya, Pakistan. Geological Bulletin of the Punjab University, 22, $13-57$.

Corrie, S. L., Kohn, M. J., \& Vervoort, J. D. (2010). Young eclogite from the Greater Himalayan Sequence, Arun Valley, eastern Nepal: P-T-t path and tectonic implications. Earth and Planetary Science Letters, 289(3), 406-416.

Cottle, J. M., Jessup, M. J., Newell, D. L., Horstwood, M. S. A., Noble, S. R., Parrish, R. R., Waters, D. J., \& Searle, M. P. (2009). Geochronology of granulitized eclogite from the Ama Drime Massif: implications for the tectonic evolution of the South Tibetan Himalaya. Tectonics, 28(1).

Darling, J. R., Storey, C. D., \& Engi, M. (2012). Allanite U-Th-Pb geochronology by laser ablation ICPMS. Chemical Geology, 292, 103-115.

de Capitani, C., \& Petrakakis, K. (2010). The computation of equilibrium assemblage diagrams 
with Theriak/Domino software. American Mineralogist, 95(7), 1006-1016.

Degeling, H., Eggins, S., \& Ellis, D. J. (2001). Zr budgets for metamorphic reactions, and the formation of zircon from garnet breakdown. Mineralogical Magazine, 65(6), 749-758.

El Korh, A. (2014). Ablation behaviour of allanites during U-Th-Pb dating using a quadrupole ICP-MS coupled to a 193 nm excimer laser. Chemical Geology, 371, 46-59.

Engi, M. (2017). Petrochronology based on REE-minerals: monazite, allanite, xenotime, apatite. Reviews in Mineralogy and Geochemistry, 83(1), 365-418.

Faryad, S. W., Nahodilová, R., \& Dolejš, D. (2010). Incipient eclogite facies metamorphism in the Moldanubian granulites revealed by mineral inclusions in garnet. Lithos, 114(1-2), 54-69.

Faryad, S. W., Perraki, M., \& Vrána, S. (2006). P-T evolution and reaction textures in retrogressed eclogites from Svetlik, the Moldanubian Zone (Czech Republic). Mineralogy and Petrology, 88(1), 297-319.

Ferry, J. M., \& Watson, E. B. (2007). New thermodynamic models and revised calibrations for the Ti-in-zircon and Zr-in-rutile thermometers. Contributions to Mineralogy and Petrology, 154(4), 429-437.

Forshaw, J. B., Waters, D. J., Pattison, D. R. M., Palin, R. M., \& Gopon, P. (2019). A comparison of observed and thermodynamically predicted phase equilibria and mineral compositions in mafic granulites. Journal of Metamorphic Geology, 37(2), 153-179.

Franz, G., Thomas, S., \& Smith, D. C. (1986). High-pressure phengite decomposition in the Weissenstein eclogite, Münchberger Gneiss Massif, Germany. Contributions to Mineralogy and Petrology, 92(1), 71-85.

Gieré, R., \& Sorensen, S. S. (2004). Allanite and other REE-rich epidote-group minerals. Reviews in Mineralogy and Geochemistry, 56(1), 431-493.

Gregory, C. J., Rubatto, D., Allen, C. M., Williams, I. S., Hermann, J., \& Ireland, T. (2007). Allanite micro-geochronology: a LA-ICP-MS and SHRIMP U-Th-Pb study. Chemical Geology, 245(34), 162-182. 
Groppo, C., Lombardo, B., Rolfo, F., \& Pertusati, P. (2007). Clockwise exhumation path of granulitized eclogites from the Ama Drime range (Eastern Himalayas). Journal of Metamorphic Geology, 25(1), 51-75.

Grujic, D., Warren, C. J. C. J., \& Wooden, J. L. J. L. (2011a). Rapid synconvergent exhumation of Miocene-aged lower orogenic crust in the eastern Himalaya. Lithosphere, 3(5), 346-366. https://doi.org/10.1130/L154.1

Grujic, D., Warren, C. J., \& Wooden, J. L. (2011b). Rapid synconvergent exhumation of Mioceneaged lower orogenic crust in the eastern Himalaya. Lithosphere, 3(5), 346-366.

Hartel, T. H. D., \& Pattison, D. R. M. (1996). Genesis of the Kapuskasing (Ontario) migmatitic mafic granulites by dehydration melting of amphibolite: the importance of quartz to reaction progress. Journal of Metamorphic Geology, 14(5), 591-611.

Hermann, J., Rubatto, D., Korsakov, A., \& Shatsky, V. S. (2001). Multiple zircon growth during fast exhumation of diamondiferous, deeply subducted continental crust (Kokchetav Massif, Kazakhstan). Contributions to Mineralogy and Petrology, 141(1), 66-82.

Hinton, R. W., \& Upton, B. G. J. (1991). The chemistry of zircon: variations within and between large crystals from syenite and alkali basalt xenoliths. Geochimica et Cosmochimica Acta, 55(11), 3287-3302.

Hopkinson, T. N., Harris, N. B. W., Warren, C. J., Spencer, C. J., Roberts, N. M. W., Horstwood, M. S. A., Parrish, R. R., \& EIMF. (2017). The identification and significance of pure sediment-derived granites. Earth and Planetary Science Letters, 467. https://doi.org/10.1016/j.epsl.2017.03.018

Hopkinson, T. N., Harris, N., Roberts, N. M. W., Warren, C. J., Hammond, S., Spencer, C. J., \& Parrish, R. R. (2020). Evolution of the melt source during protracted crustal anatexis: An example from the Bhutan Himalaya. Geology, 48(1), 87-91.

Horstwood, M. S. A., Košler, J., Gehrels, G., Jackson, S. E., McLean, N. M., Paton, C., Pearson, N. J., Sircombe, K., Sylvester, P., \& Vermeesch, P. (2016). Community-Derived Standards for 
LA-ICP-MS U-(Th-) Pb Geochronology-Uncertainty Propagation, Age Interpretation and Data Reporting. Geostandards and Geoanalytical Research, 40(3), 311-332.

Janots, E., Brunet, F., Goffé, B., Poinssot, C., Burchard, M., \& Cemič, L. (2007). Thermochemistry of monazite-(La) and dissakisite-(La): implications for monazite and allanite stability in metapelites. Contributions to Mineralogy and Petrology, 154(1), 1-14.

Janots, E., Engi, M., Berger, A., Allaz, J., Schwarz, J., \& Spandler, C. (2008). Prograde metamorphic sequence of REE minerals in pelitic rocks of the Central Alps: implications for allanite-monazite-xenotime phase relations from 250 to 610 C. Journal of Metamorphic Geology, 26(5), 509-526.

Janots, E., Engi, M., Rubatto, D., Berger, A., Gregory, C., \& Rahn, M. (2009). Metamorphic rates in collisional orogeny from in situ allanite and monazite dating. Geology, 37(1), 11-14.

Kali, E., Leloup, P. H., Arnaud, N., Mahéo, G., Liu, D., Boutonnet, E., Van der Woerd, J., Liu, X., Liu-Zeng, J., \& Li, H. (2010). Exhumation history of the deepest central Himalayan rocks, Ama Drime range: Key pressure-temperature-deformation-time constraints on orogenic models. Tectonics, 29(2).

Kellett, D. A., Cottle, J. M., \& Smit, M. (2014). Eocene deep crust at Ama Drime, Tibet: Early evolution of the Himalayan orogen. Lithosphere, 6(4), 220-229.

Kellett, D. A., Grujic, D., \& Erdmann, S. (2009). Miocene structural reorganization of the South Tibetan detachment, eastern Himalaya: Implications for continental collision. Lithosphere, 1(5), 259-281.

Knott, T. R., Branney, M. J., Reichow, M. K., Finn, D. R., Coe, R. S., Storey, M., Barfod, D., \& McCurry, M. (2016). Mid-Miocene record of large-scale Snake River-type explosive volcanism and associated subsidence on the Yellowstone hotspot track: The Cassia Formation of Idaho, USA. Bulletin, 128(7-8), 1121-1146.

Lanari, P., Vidal, O., De Andrade, V., Dubacq, B., Lewin, E., Grosch, E. G., \& Schwartz, S. (2014). XMapTools: A MATLABC-based program for electron microprobe X-ray image processing 
and geothermobarometry. Computers \& Geosciences, 62, 227-240.

Li, D., Liao, Q., Yuan, Y., Wan, Y., Liu, D., Zhang, X., Yi, S., Cao, S., \& Xie, D. (2003). SHRIMP U-Pb zircon geochronology of granulites at Rimana (Southern Tibet) in the central segment of Himalayan Orogen. Chinese Science Bulletin, 48(23), 2647-2650.

Liu, Y., Siebel, W., Massonne, H.-J., \& Xiao, X. (2007). Geochronological and petrological constraints for tectonic evolution of the central Greater Himalayan Sequence in the Kharta area, southern Tibet. The Journal of Geology, 115(2), 215-230.

Lombardo, B., \& Rolfo, F. (2000). Two contrasting eclogite types in the Himalayas: implications for the Himalayan orogeny. Journal of Geodynamics, 30(1), 37-60.

Lombardo, B., Rolfo, F., \& McClelland, W. C. (2016). A review of the first eclogites discovered in the Eastern Himalaya. European Journal of Mineralogy, 28(6), 1099-1109.

Loury, C., Rolland, Y., Cenki-Tok, B., Lanari, P., \& Guillot, S. (2016). Late Paleozoic evolution of the South Tien Shan: Insights from P-T estimates and allanite geochronology on retrogressed eclogites (Chatkal range, Kyrgyzstan). Journal of Geodynamics, 96, 62-80.

Marsh, J. H., \& Kelly, E. D. (2017). Petrogenetic relations among titanium-rich minerals in an anatectic high-P mafic granulite. Journal of Metamorphic Geology, 35(7), 717-738.

Marsh, J. H., \& Smye, A. J. (2017). U-Pb systematics and trace element characteristics in titanite from a high-pressure mafic granulite. Chemical Geology, 466, 403-416.

Matthews, A., \& Goldsmith, J. R. (1984). The influence of metastability on reaction kinetics involving zoisite formation from anorthite at elevated pressures and temperatures. American Mineralogist, 69(9-10), 848-857.

McFarlane, C. R. M. (2016). Allanite UPb geochronology by 193 nm LA ICP-MS using NIST610 glass for external calibration. Chemical Geology, 438, 91-102.

Möller, C., Andersson, J., Dyck, B., \& Lundin, I. A. (2015). Exhumation of an eclogite terrane as a hot migmatitic nappe, Sveconorwegian orogen. Lithos, 226, 147-168. 
Montomoli, C., laccarino, S., Carosi, R., Langone, A., \& Visonà, D. (2013). Tectonometamorphic discontinuities within the Greater Himalayan Sequence in Western Nepal (Central Himalaya): Insights on the exhumation of crystalline rocks. Tectonophysics, 608, 13491370.

Murali, A. V, Parthasarathy, R., Mahadevan, T. M., \& Das, M. S. (1983). Trace element characteristics, REE patterns and partition coefficients of zircons from different geological environments-a case study on Indian zircons. Geochimica et Cosmochimica Acta, 47(11), 2047-2052.

Nábělek, J., Hetényi, G., Vergne, J., Sapkota, S., Kafle, B., Jiang, M., Su, H., Chen, J., \& Huang, B.S. (2009). Underplating in the Himalaya-Tibet collision zone revealed by the Hi-CLIMB experiment. Science, 325(5946), 1371-1374.

O’Brien, P. J. (2019). Eclogites and other high-pressure rocks in the Himalaya: a review. Geological Society, London, Special Publications, 483(1), 183-213.

O’Brien, P. J., \& Rötzler, J. (2003). High-pressure granulites: formation, recovery of peak conditions and implications for tectonics. Journal of Metamorphic Geology, 21(1), 3-20.

Oberli, F., Meier, M., Berger, A., Rosenberg, C. L., \& GierÉ, R. (2004). U-Th-Pb and 230Th/238U disequilibrium isotope systematics: Precise accessory mineral chronology and melt evolution tracing in the Alpine Bergell intrusion. Geochimica et Cosmochimica Acta, 68(11), $2543-2560$.

Otamendi, J. E., de La Rosa, J. D., Douce, A. E. P., \& Castro, A. (2002). Rayleigh fractionation of heavy rare earths and yttrium during metamorphic garnet growth. Geology, 30(2), 159162.

Patiño Douce, A. E., \& Beard, J. S. (1995). Dehydration-melting of biotite gneiss and quartz amphibolite from 3 to 15 kbar. Journal of Petrology, 36(3), 707-738.

Pognante, U., Benna, P., \& Le Fort, P. (1993). High-pressure metamorphism in the High Himalayan crystallines of the Stak valley, northeastern Nanga Parbat-Haramosh syntaxis, 
Pakistan Himalaya. Geological Society, London, Special Publications, 74(1), 161-172.

Pognante, U., \& Spencer, D. A. (1991). First report of eclogites from the Himalayan belt, Kaghan valley (northern Pakistan). European Journal of Mineralogy, 613-618.

Powell, R., \& Holland, T. J. B. (1988). An internally consistent dataset with uncertainties and correlations: 3. Applications to geobarometry, worked examples and a computer program. Journal of Metamorphic Geology, 6(2), 173-204. https://doi.org/10.1111/j.15251314.1988.tb00415.x

Regis, D., Warren, C. J., Young, D., \& Roberts, N. M. W. (2014a). Tectono-metamorphic evolution of the Jomolhari massif: Variations in timing of syn-collisional metamorphism across western Bhutan. Lithos, 190-191. https://doi.org/10.1016/j.lithos.2014.01.001

Regis, D., Warren, C. J., Young, D., \& Roberts, N. M. W. (2014b). Tectono-metamorphic evolution of the Jomolhari massif: Variations in timing of syn-collisional metamorphism across western Bhutan. Lithos, 190, 449-466. https://doi.org/10.1016/j.lithos.2014.01.001

Rolfo, F., Carosi, R., Montomoli, C., \& Visonà, D. (2008). Discovery of granulitized eclogite in North Sikkim expands the Eastern Himalaya high-pressure province. Himalayan Journal of Sciences, 5(7), 126-127.

Rubatto, D. (2002). Zircon trace element geochemistry: partitioning with garnet and the link between U-Pb ages and metamorphism. Chemical Geology, 184(1), 123-138.

Schaltegger, U., Fanning, C. M., Günther, D., Maurin, J. C., Schulmann, K., \& Gebauer, D. (1999). Growth, annealing and recrystallization of zircon and preservation of monazite in highgrade metamorphism: conventional and in-situ $\mathrm{U}-\mathrm{Pb}$ isotope, cathodoluminescence and microchemical evidence. Contributions to Mineralogy and Petrology, 134(2), 186-201.

Sigoyer, J. De, Guillot, S., Lardeaux, J.-M., \& Mascle, G. (1997). Glaucophane-bearing eclogites in the Tso Morari dome (eastern Ladakh, NW Himalaya). European Journal of Mineralogy, 1073-1084.

Skora, S., Baumgartner, L. P., Mahlen, N. J., Johnson, C. M., Pilet, S., \& Hellebrand, E. (2006). 
Diffusion-limited REE uptake by eclogite garnets and its consequences for $\mathrm{Lu}-\mathrm{Hf}$ and SmNd geochronology. Contributions to Mineralogy and Petrology, 152(6), 703-720.

Smye, A. J., Bickle, M. J., Holland, T. J. B., Parrish, R. R., \& Condon, D. J. (2011). Rapid formation and exhumation of the youngest Alpine eclogites: a thermal conundrum to Barrovian metamorphism. Earth and Planetary Science Letters, 306(3-4), 193-204.

Smye, A. J., Roberts, N. M. W., Condon, D. J., Horstwood, M. S. A., \& Parrish, R. R. (2014). Characterising the $\mathrm{U}-\mathrm{Th}-\mathrm{Pb}$ systematics of allanite by ID and LA-ICPMS: Implications for geochronology. Geochimica et Cosmochimica Acta, 135, 1-28.

Sorensen, S. S. (1991). Petrogenetic significance of zoned allanite in garnet amphibolites from a paleo-subduction zone: Catalina Schist, southern California. American Mineralogist, 76(34), 589-601.

Spear, F. S. (2010). Monazite-allanite phase relations in metapelites. Chemical Geology, 279(12), 55-62.

Spencer, C. J., Roberts, N. M. W., Cawood, P. A., Hawkesworth, C. J., Prave, A. R., Antonini, A. S. M., \& Horstwood, M. S. A. (2014). Intermontane basins and bimodal volcanism at the onset of the Sveconorwegian Orogeny, southern Norway. Precambrian Research, 252, 107-118.

St-Onge, M. R., Rayner, N., Palin, R. M., Searle, M. P., \& Waters, D. J. (2013). Integrated pressure-temperature-time constraints for the T so $\mathrm{M}$ orari dome ( $\mathrm{N}$ orthwest I ndia): implications for the burial and exhumation path of UHP units in the western $\mathrm{H}$ imalaya. Journal of Metamorphic Geology, 31(5), 469-504.

Stacey, J. S. t, \& Kramers, 1JD. (1975). Approximation of terrestrial lead isotope evolution by a two-stage model. Earth and Planetary Science Letters, 26(2), 207-221.

Van Hinsbergen, D. J. J., Lippert, P. C., Dupont-Nivet, G., McQuarrie, N., Doubrovine, P. V, Spakman, W., \& Torsvik, T. H. (2012). Greater India Basin hypothesis and a two-stage Cenozoic collision between India and Asia. Proceedings of the National Academy of 
Vermeesch, P. (2018). IsoplotR: A free and open toolbox for geochronology. Geoscience Frontiers, 9(5), 1479-1493.

Wang, J.-M., Lanari, P., Wu, F.-Y., Zhang, J.-J., Khanal, G. P., \& Yang, L. (2021). First evidence of eclogites overprinted by ultrahigh temperature metamorphism in Everest East, Himalaya: Implications for collisional tectonics on early Earth. Earth and Planetary Science Letters, 558,116760 .

Wang, Y., Zhang, L., Zhang, J., \& Wei, C. (2017). The youngest eclogite in central Himalaya: P-T path, U-Pb zircon age and its tectonic implication. Gondwana Research, 41, 188-206.

Warren, C. J., Grujic, D., Cottle, J. M., \& Rogers, N. W. (2012). Constraining cooling histories: rutile and titanite chronology and diffusion modelling in NW Bhutan. Journal of Metamorphic Geology, 30(2), 113-130.

Warren, C. J., Grujic, D., Kellett, D. A., Cottle, J., Jamieson, R. A., \& Ghalley, K. S. (2011). Probing the depths of the India-Asia collision: U-Th-Pb monazite chronology of granulites from NW Bhutan. Tectonics, 30(2). https://doi.org/10.1029/2010TC002738

Whitney, D. L., \& Evans, B. W. (2010). Abbreviations for names of rock-forming minerals. American Mineralogist, 95(1), 185. 